\title{
Food for Thought in the Souillac Pillar: Devouring Beasts, Pain and the Subversion of Heroic Codes of Violence
}

\section{Carol Knicely}

\section{Volume 24, numéro 2, 1997}

Breaking the Boundaries: Intercultural Perspectives in Medieval Art Entamer les frontières : perspectives interculturelles dans l'art du Moyen-Âge

URI : https://id.erudit.org/iderudit/1071664ar

DOI : https://doi.org/10.7202/1071664ar

Aller au sommaire du numéro

\section{Éditeur(s)}

UAAC-AAUC (University Art Association of Canada | Association d'art des universités du Canada)

\section{ISSN}

0315-9906 (imprimé)

1918-4778 (numérique)

Découvrir la revue

Citer cet article

Knicely, C. (1997). Food for Thought in the Souillac Pillar: Devouring Beasts, Pain and the Subversion of Heroic Codes of Violence. RACAR : Revue d'art canadienne / Canadian Art Review, 24(2), 14-37.

https://doi.org/10.7202/1071664ar

\section{Résumé de l'article}

Sculptée sur la face avant du large pilier de l'église de Souillac, la représentation de bêtes sauvages déchiquetant leur proie a toujours fasciné les visiteurs. Pour les chercheurs cependant, sa complexité et son ambiguité se sont toujours révélées difficiles à interpréter. La manière de représenter le motif découle d'une tradition animalière destinée à rehausser la vaillance masculine. Ce traitement traditionnel se trouve ici contredit par l'apparition, dans la partie supérieure du pilier, d'un homme nu, sans défense et attaqué par des animaux qui lui infligent des sévices corporels. Le pilier tient ainsi deux discours distincts et radicalement opposés sur la souffrance. Le premier reste relié aux moeurs des seigneurs féodaux et le second à l'ordre monastique. En transgressant ces frontières bien établies, l'image produit du sens et un impact psychologique par la confrontation de ces deux discours antagonistes. Il transforme la mentalité guerrière féodale, celle qui dénie la souffrance et la peur de la mort, et propose une autre vision plus près de la perception et des intérêts défendus par l'ordre monastique. En effet, pour celui-ci, la souffrance (physique et spirituelle) aussi bien que la peur de la mort se trouvent à être des éléments essentiels au futur triomphe de l'âme. Les images sculptées et leur iconographie contribuent donc dans leur originalité programmatique au changement des attitudes sociales et religieuses qui marquent la société laïque du sceau de la culpabilité. Je soutiens donc ici que les sculptures du portail de Souillac participent visuellement, dès le XIIe siècle, à la transformation radicale des mentalités.
Tous droits réservés @ C UAAC-AAUC (University Art Association of Canada | Association d'art des universités du Canada), 2000
Ce document est protégé par la loi sur le droit d'auteur. L'utilisation des services d'Érudit (y compris la reproduction) est assujettie à sa politique d'utilisation que vous pouvez consulter en ligne.

https://apropos.erudit.org/fr/usagers/politique-dutilisation/ 


\title{
Food for Thought in the Souillac Pillar: Devouring Beasts, Pain and the Subversion of Heroic Codes of Violence
}

\author{
Carol Knicely, University of British Columbia
}

\begin{abstract}
Résumé

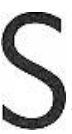
culptée sur la face avant du large pilier de l'église de Souillac, la représentation de bêtes sauvages déchiquetant leur proie a toujours fasciné les visiteurs. Pour les chercheurs cependant, sa complexité et son ambiguité se sont toujours révélées difficiles à interpréter. La manière de représenter le motif découle d'une tradition animalière destinée à rehausser la vaillance masculine. Ce traitement traditionnel se trouve ici contredit par l'apparition, dans la partie supérieure du pilier, d'un homme nu, sans défense et attaqué par des animaux qui lui infligent des sévices corporels. Le pilier tient ainsi deux discours distincts et radicalement opposés sur la souffrance. Le premier reste relié aux mœurs des seigneurs féodaux et le second à l'ordre monastique. En transgressant ces frontières bien établies, l'image produit du sens et un impact psychologique par la
\end{abstract}

confrontation de ces deux discours antagonistes. II transforme la mentalité guerrière féodale, celle qui dénie la souffrance et la peur de la mort, et propose une autre vision plus près de la perception et des intérêts défendus par l'ordre monastique. En effet, pour celui-ci, la souffrance (physique et spirituelle) aussi bien que la peur de la mort se trouvent à être des éléments essentiels au futur triomphe de l'âme. Les images sculptées et leur iconographie contribuent donc dans leur originalité programmatique au changement des attitudes sociales et religieuses qui marquent la société laique du sceau de la culpabilité. Je soutiens donc ici que les sculptures du portail de Souillac participent visuellement, dès le Xlle siècle, à la transformation radicale des mentalités. $t$ is a rare viewer who would not agree with the opinion of Andreas Petzold when he pronounced the large pillar at Souillac (fig. 1) one of "the most compelling of all Romanesque sculptural groups." There is a disturbing quality in this amazing imagery of devouring beasts because it combines the aesthetic pleasures of stylized interlacing of finely carved, tautly crossed animal bodies together with the unabashed aggressive violence of the beast attack. Scholars, who generally agree the pillar was originally designed to be a trumeau for a portal in this former monastic church, are captivated but remain bewildered by the complexity and ambiguity of this evocative imagery. Perhaps most disturbing, the ultimate victim of this violence is a pitiful human figure with an unusually explicit expression of pain on his face. Naked, he is seated precariously on the backs of a crossed lion and griffin that wrench their heads around the colonnettes, the griffin coming back to bite into his right side, while the lion grabs the man's head in his maw from the other direction. Below, caught in the gripping mouths of the bestial interlace down the front of the pillar, a bird, a stag and a dog suffer a similar fate. While the representation does not conform to traditional iconographic subjects, it seems to be much more than merely decorative. It is for this reason that Michael Camille employed the pillar as a perfect candidate for what he calls an "Anti-Iconography of Medieval Art," a representation that defies standard art historical methods of text-based explanation. ${ }^{2}$ He argued for the necessity to attend to the somatic qualities of the pillar and contemplate potential reactions in a range of audiences. Earlier in the century, Meyer Schapiro had also argued that this image could not be circumscribed by interpretation based on religious doctrine. In fact, Schapiro described it as a "nonreligious fantasy of rapacious beasts," and sought to retain a certain ambivalence by saying that it evoked either "a fear of violence or the respect for aggressive force." 3 In spite of or even because of this violence, the pillar's ability to elicit fantasies and desires is certainly part of its long-lasting appeal.

The Portal

The aim of this article is to investigate what might trigger a sense of both ambivalence and awe toward this sculpture, be it by contemporary scholars or medieval viewers. But first, it will be useful to review the general circumstances of portal construction at this time, since the large pillar was part of an ambitious portal complex planned for the monastic church of St Marie at Souillac in an era when monumental portal programmes had just begun to proliferate. Although not firmly dated, the Souillac portal sculptures were probably sculpted around 1135-40 and bear close affinities in style and motif to the important Languedoc portals of the Cluniac abbeys of Moissac and Beaulieu-surDordogne. These new portals were confident expressions of the wealth and prestige that had accrued to ecclesiastical establishments, especially monasteries, in the wake of the Gregorian Reforms of the eleventh century, the growth of international pilgrimage and the success of crusades in Jerusalem and Spain. With reformed Benedictine monasteries like Cluny and Souillac's mother house, Aurillac, in the lead, the church had struggled to shed itself from corruption and direct domination by lay feudal lords in order to establish itself as an independent but vital sector in society. "Those who pray" had fully entered the feudal imagination as a distinct but integral order in a concept 
Figure I. Souillac, former monastic Church of Sainte-Marie. Front face of the Large Pillar (often called a trumeau) against the west wall, ca. 1/20-40 (Photo: A. Allemand).

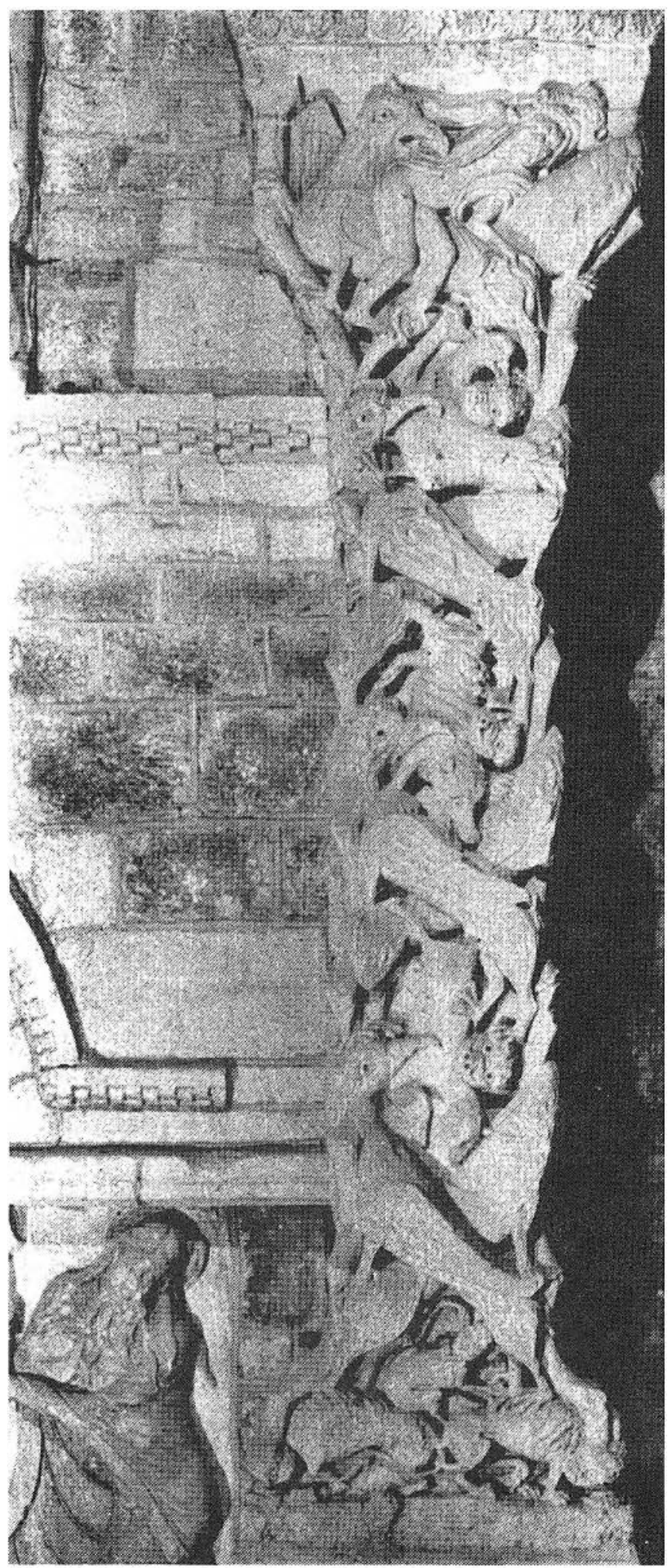

of society divided neatly into a mutually dependent tripartite hierarchy of "those who pray," "those who fight" and "those who work."

Differing from other forms of architectural sculprure and decor, these monumental portals were pointedly public in nature. While contributing to the self-identity of the monks themselves, they could be directed to a range of audiences. Even in the normally closed communities of monks such as Souillac, church portals opened onto passageways that led to public squares or roads and were accessible to the wider lay public. Thus, the portal served as a threshold from profane to sacred space inscribing a symbolic meeting point between worlds of the laity and the clergy. ${ }^{6}$

While confident expressions, it is important to recognize that the era of the "Great Portals" (1120s-1140s) was, in fact, a period of deep transition in the church, marked by controversy, economic problems and frequent conflicts, not only with lay authorities and townspeople, but also between different branches and institutions of the ecclesiastical establishment itself. Moreover, within monasticism renewed calls for reform were heard, and new religious orders espousing a more inward form of spirituality came into being (e.g. Grandmont, Fontevrault, Cistercians), often attracting the donations of rich feudal lords that had once gone to the older Benedictine establishments. ${ }^{8}$ While Bernard of Clairvaux, the esteemed leader of the Cistercians and future saint, hotly critiqued the older Bencdictines' use of lavish art to attract the laity (who, in his vicw, should have no business in monasteries to begin with), ? many monastic churches, as recent scholarship indicates, felt compelled to produce public portals precisely in order to assert their position in this period of competition and conflict. ${ }^{10}$ The monastery at Souillac was no exception. As we shall see, in its eagerness to address and influence a wider audience beyond the doors of its community it employed unique means to achieve its ends.

What is so unusual about the Souillac portal sculptures and the large pillar, in particular, is the way the imagery pointedly draws on the lay and monastic worlds and works to bring them together. Within a set of representations geared to have an impact on the sensibilities of a lay audience, the pillar imagery, I will argue, crosses boundaries, presents a confrontation of discourses and distinct reversals of expectation. In what amounts to a politics of style, it calls up secular notions of manly heroic valour, only to contradict these with the inclusion of the man attacked by beasts who appears to bc in so much pain, a portrayal more in tune with monastic subjectivity and spirituality. This clash was intended to jolt those viewers who took pride in values of combative manly heroism and saw this as the epitome of social worth. In this era, this 
Figure 2. Souillac, former monastic Church of Sainte-Marie. Portal sculptures against the west wall, ca. II20-40 (Photo: Guillet-Lescuyer).

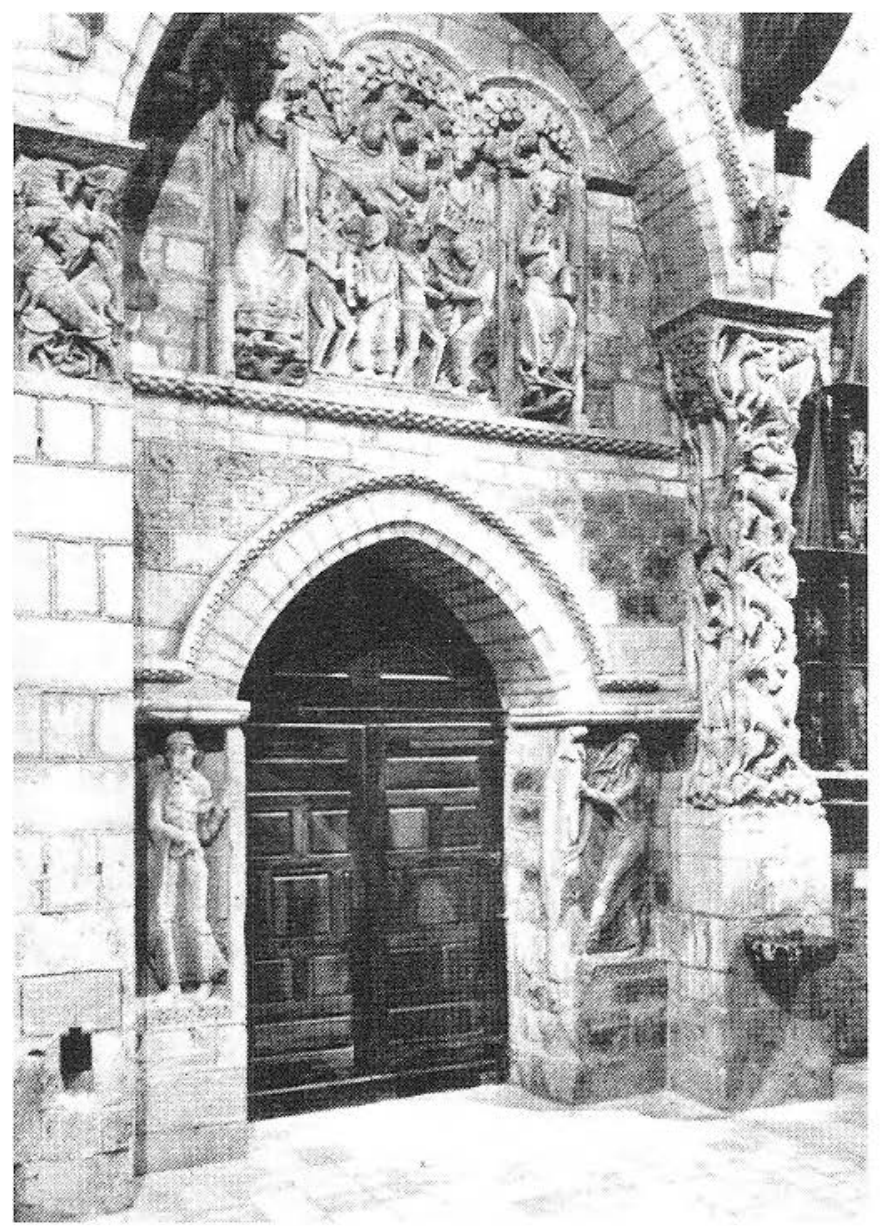

would include almost everybody in society, but it would be most disturbing to those feudal warriors who saw themselves directly embodying this position.

In short, a visual language and sensibility normally associated with the dominant class of lay feudal lords is appropriated but then reworked in order to teach a spiritual lesson that was monastic and in the interests of the monastery.

\section{The Souillac Ensemble}

Clearly, the present disposition of the Souillac sculptures around the west portal facing the inside rather than the outside of the church is unusual, and this has been a topic of much debate ${ }^{11}$ (fig. 2). This arrangement appears to go against the concept of the public nature of the portal outlined above. Yet, the existence of the large pillar, almost certainly conccived to be a central trumeau of the kind necessary to support a heavy lintel and tympanum, suggests, at least at some point, that there were plans for a monumental public-oriented portal like those at
Figure 3. Moissac, former abbey Church of Saint-Pierre. South Portal with tympanum of Christ in the Second Coming, ca. 1115-30 (Photo: Henri Guilbaut).

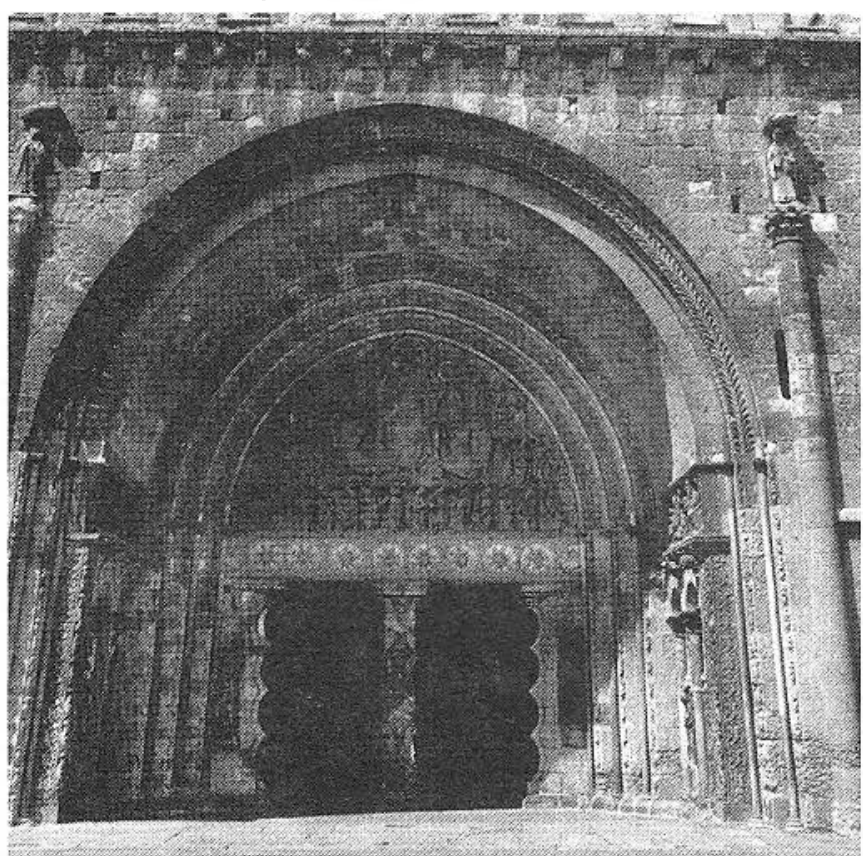

Figure 4. Beaulieu, former abbey Church of Saint-Pierre. South Portal with tympanum of Christ in the Last Judgement, ca. 1130 (Photo: author).

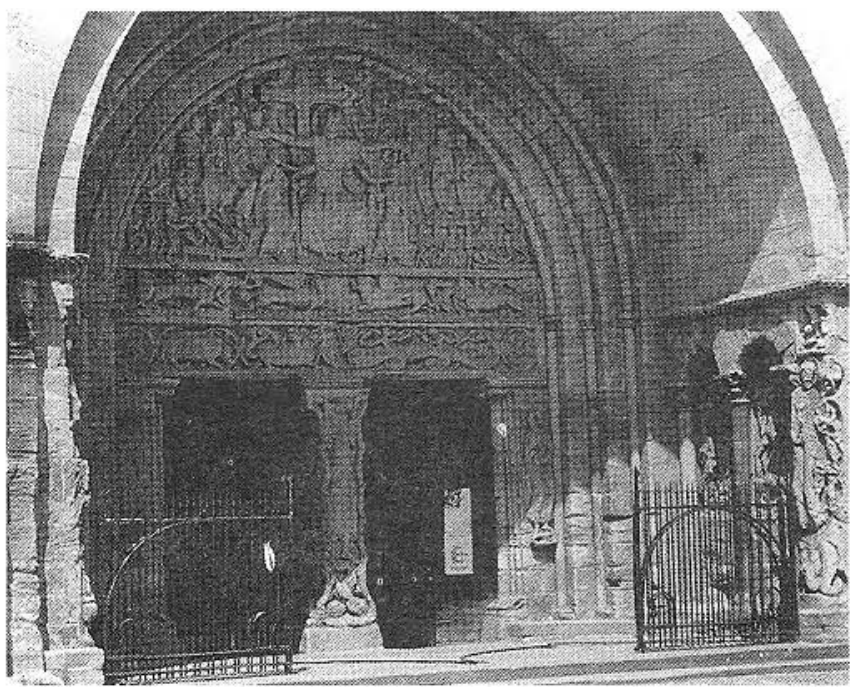

Moissac and Beaulieu. Comparable to the trumeaux of these abbcys, the pillar is sculpted on three sides with a base and splayed impost; it has scalloped colonnettes like Beaulicu and crossed beasts reminiscent of the trumeau at Moissac (figs. $3 \&$ 4). However, the large pillar now stands to the right of the doorway that opens onto an eleventh-century tower porch, not at ground level or centralized, as would be the case had it been 
Figure 5. Souillac, former monastic Church of Sainte-Marie. The story of Theophilus, flanked by a seated abbot and Saint Peter, in the relief above the west doonway, ca. $1120-40$ (Photo: A. Allemand).

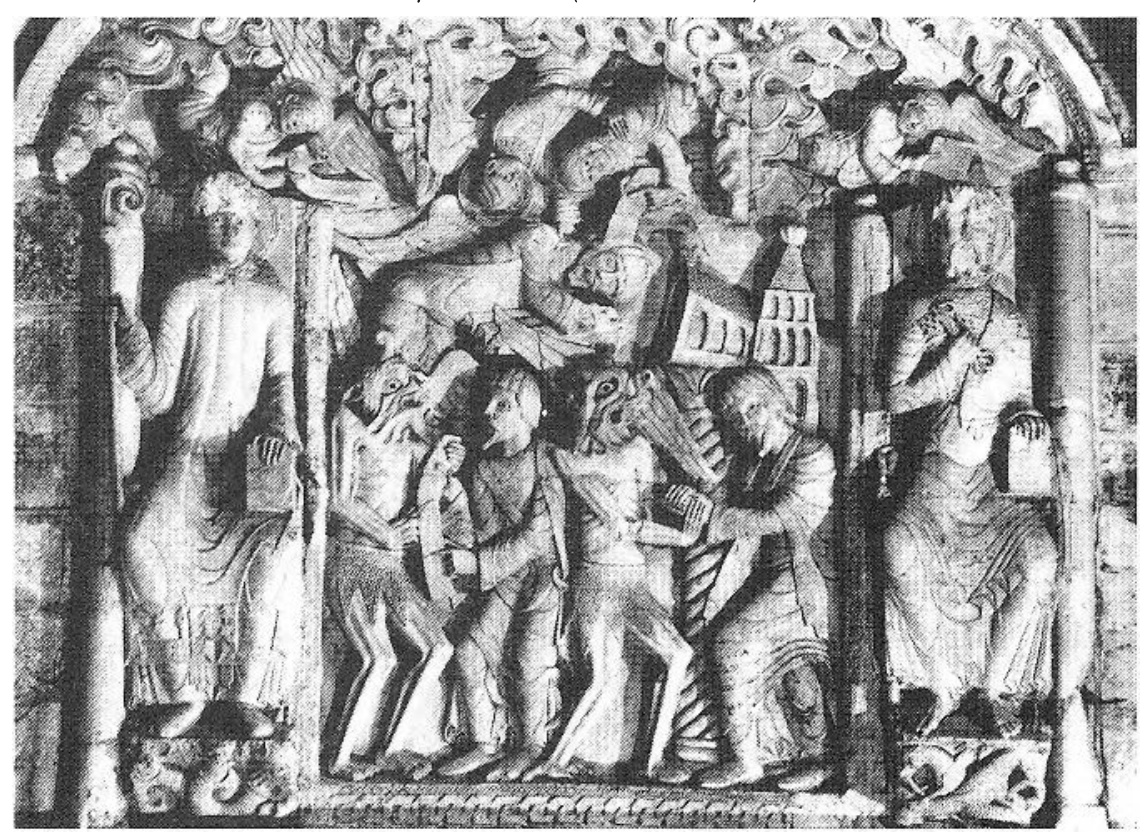

(possibly during the depredations of the Religious Wars in the sixteenth century) or, more simply, never completed to the original grand scale. Regis Labourdette has put forward the most convincing theory, arguing that in spite of their seeming irregularities (indeed because of them), the Souillac sculptures probably had more or less this arrangement since medieval times. ${ }^{14}$ It would seem that the sculptures were originally set up in this same manner on the opposite side of the west portal facing the interior of the tower porch but were probably moved to the inside during restorations of the porch entry in the seventeenth century. Significantly, the portal rests just above a burial crypt that lies beneath this threshold. The sculptures, therefore, would have framed this main entrance into the church positioned in the rather limited space of the interior of the eleventh-century porch. Labourdette

placed as a trumeau. Instead, it is raised on a pier and serves to support the springing of a blind arch over the portal while a smaller relief of crossed lions attacking a ram is set into the pier under the arch on the other side of the portal. As at Moissac and Beaulieu the doorway is flanked by jamb figures, here Joseph and the celebrated Isaiah, but remarkably the portal does not have the usual semicircular tympanum with the customary centralized image of Christ. Instead, there is an irregularly shaped trefoil arch over a relief portraying a miracle of the Virgin. Surprisingly, as Schapiro remarked in 1939, the prized central position has been given over to a story of lay apostasy, ${ }^{12}$ the Legend of Theophilus, a sixth-century church administrator, who sold his soul to the Devil, later repented, and was saved through prayer to the Virgin (fig. 5). The choice of this story with a lay protagonist is yet another indication that the designers of the portal were making special efforts to address a lay audience. While it is understandable that the monastery at Souillac, dedicated to the Virgin, might be interested in propagating this miracle in order to advertise the value of patronizing a sanctuary where her powers of intercession could be accessed, the portrayal of a non-biblical legend in such a prominent location was unprecedented, especially without any figure of Christ. ${ }^{13}$ There are many good reasons to conclude that this relief may originally have been conceived for a porch setting, including its moralizing subject matter and the prominence of the Devil, features that are comparable to the porch reliefs of Moissac, with its Parable of Lazarus and Dives (fig. 6), and Beaulieu (Temptations of Christ). The debate among art historians has been whether the original larger portal was destroyed contends that the large pillar, meant to be a trumeau, is the only element of the Souillac sculptures that was assuredly made in accordance with an original scheme for a large portal complex. This large portal, however, was not destroyed, as many have assumed, but was probably never built. ${ }^{15}$ The other sculptural pieces all have anomalies that suggest they were adapted for this unusual constricted space. In any case, the domed church at Souillac, which cannot be dated precisely through documentation, but was built some time in the twelfth century, has no doorway wide enough to accommodate a trumeau the size of the large pillar at Souillac. The intricacy of the imagery on this pillar, sculpted so elaborately on three sides with three different genres of imagery, is much more complex than the trumeau schemes at Moissac and Beaulieu. One wonders if the sculptors and planners were not already attempting to load the pillar with such densely meaningful imagery because they already had the suspicion that the full portal would not be completed. The left side of the pillar presents an ambitious narrative portrayal of Abraham about to sacrifice his son, Isaac (fig. 7a). On the right, however, there is a rather enigmatic coupling of three pairs of figures, stacked one above the other, each composed of a young and an older man (fig. 7b). As Schapiro observed, this seems to be a profane parody on the theme of filial piety and obedience at the heart of the venerable Abraham-Isaac story depicted on the other side. ${ }^{16}$ The older man and youth of the bottom two pairs are stripped to the waist like wrestlers, but it is hard to tell if their embrace is meant to be aggressive or friendly. ${ }^{17}$ In the upper pair, the young boy, fully clothed, bows his head much like Isaac with his hands in prayer while the older man, in a 
Figure 6. Moissac, former abbey Church of Saint-Pierre. The story of Lazarus and the Rich Man, Dives; below, Demons with Avarice and Luxuria, ca. II30 (Photo: Henri Guilbaut).

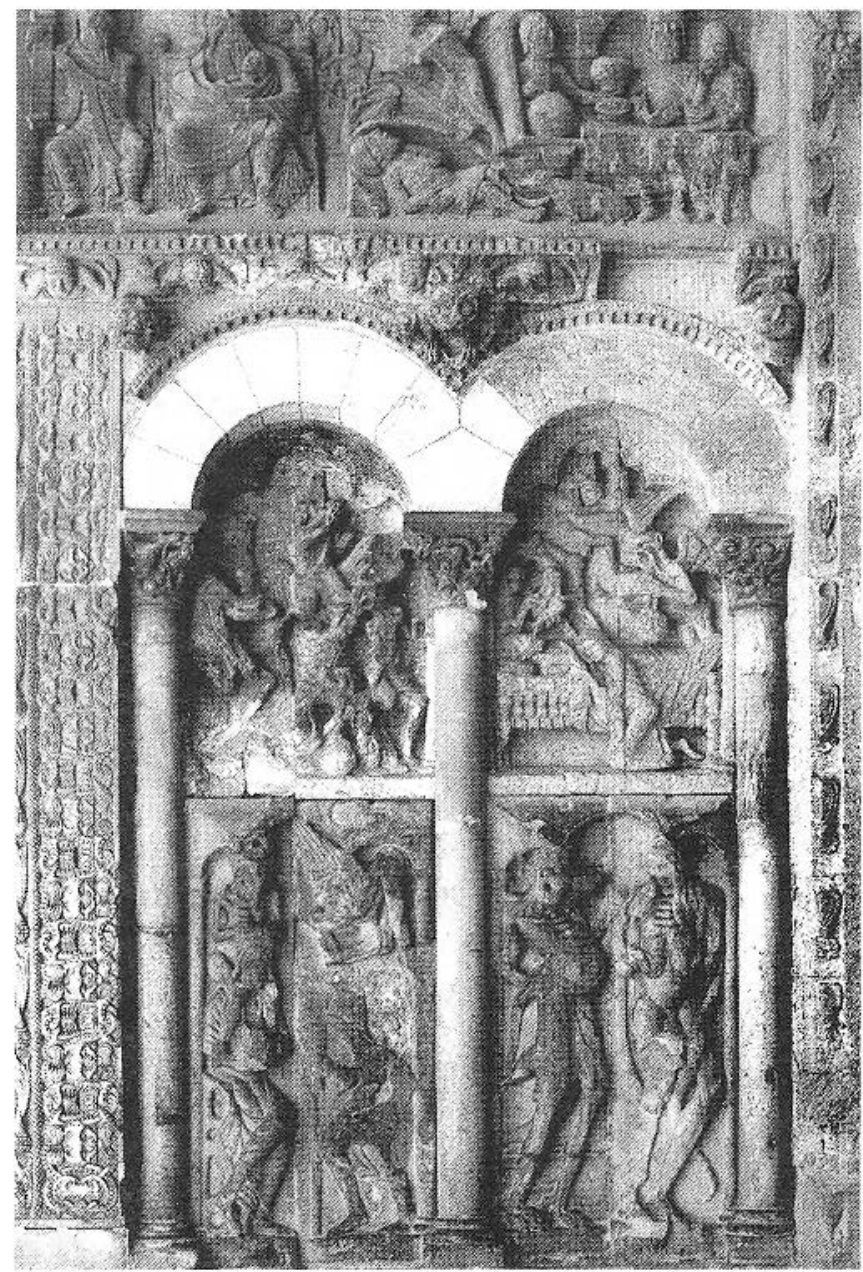

gesture similar to Abraham, violently pulls on the boy's hair as his own head and face is unceremoniously trod upon by the claws of a heavy bird.

Let me return now to the front face of the large pillar with its acrobatic bodies of lions and griffins who seem to construct the pillar as they cross and stand on top of each other, insidiously maintaining its structure by virtue of their deadly mauling grasps onto the victims held tight between them. Amidst this grouping of animal prey, the smooth white naked body of the human figure stands out sharply at the top (figs. $1 \& 8$ ). The manifestation of pain through the discomfort of his body and the unusually explicit facial features are rare for Romanesque art. The man's eyes are dim, suggesting he is faint with the agony. His brow is furrowed, and deep folds crease his cheeks around a falling jaw and mouth open with a moan. ${ }^{18}$ Pain seems to be a major concern here. Yet, as I will demonstrate, such a portrayal of human pain is particularly surprising in the context of what is otherwise a genre of imagery derived from heroic
Figure 7a. Souillac, former monastic Church of Sainte-Marie. Left side of the Large Pillar. An angel bringing a ram stops the hand of Abraham about to sacrifice his son, Isaac, ca. 1130 (Photo: A. Allemand).

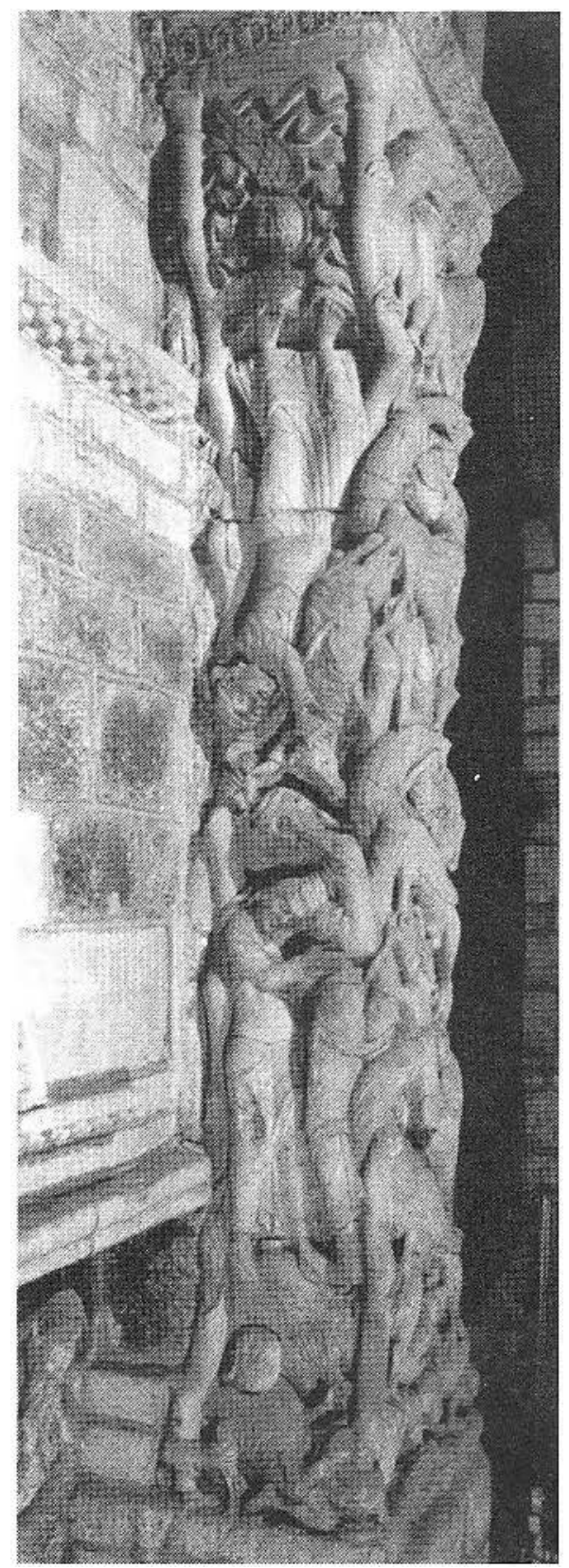

traditions of male bravado especially dear to the warrior class of the feudal era, a class, we shall see, that generally refused to acknowledge physical pain.

Indeed, a key that might unlock the incongruities of this image revolves around the issue of pain, embodied here in the image of the suffering man attacked by beasts. Physical pain in any era, as Elaine Scarry has reminded us so forcefully, is notoriously difficult to represent because it is an interior feeling. ${ }^{19}$ Moreover, even the very apprehension of pain, including the varying degrees of its toleration, is not something that is univer- 
Figure 7b. Souillac, former monastic Church of SainteMarie. Right side of the Large Pillar. Three pairs of embracing or wrestling figures of a youth and an older man, ca. 1130 (Photo: Guillet-Lescuyer).

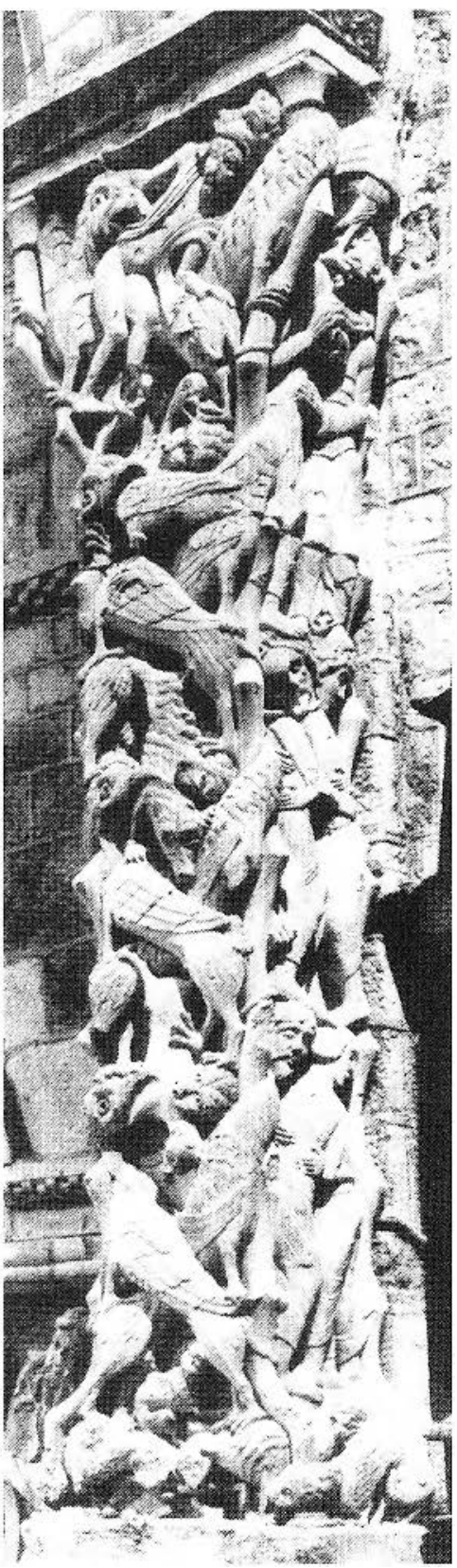

sal to all societies or to all individuals in any one society. Perceived notions about pain tolerance have, of course, also been used to characterize classes of individuals, frequently underpinned by suggestions of innate differences due to age or gender. "Children and women suffer pain but 'real' men do not," is an adage that has traversed many centuries of Western cultural tradition. The Souillac image was produced at a moment when there were two very distinct, radically different discourses about pain and the importance that could be attached to the experience and consideration of pain. In a striking
Figure 8. Souillac, former monastic Church of Sainte-Marie. Top of the Large Pillar. Detail of man attacked by beasts, ca. II30 (Photo: Maurice Babey).

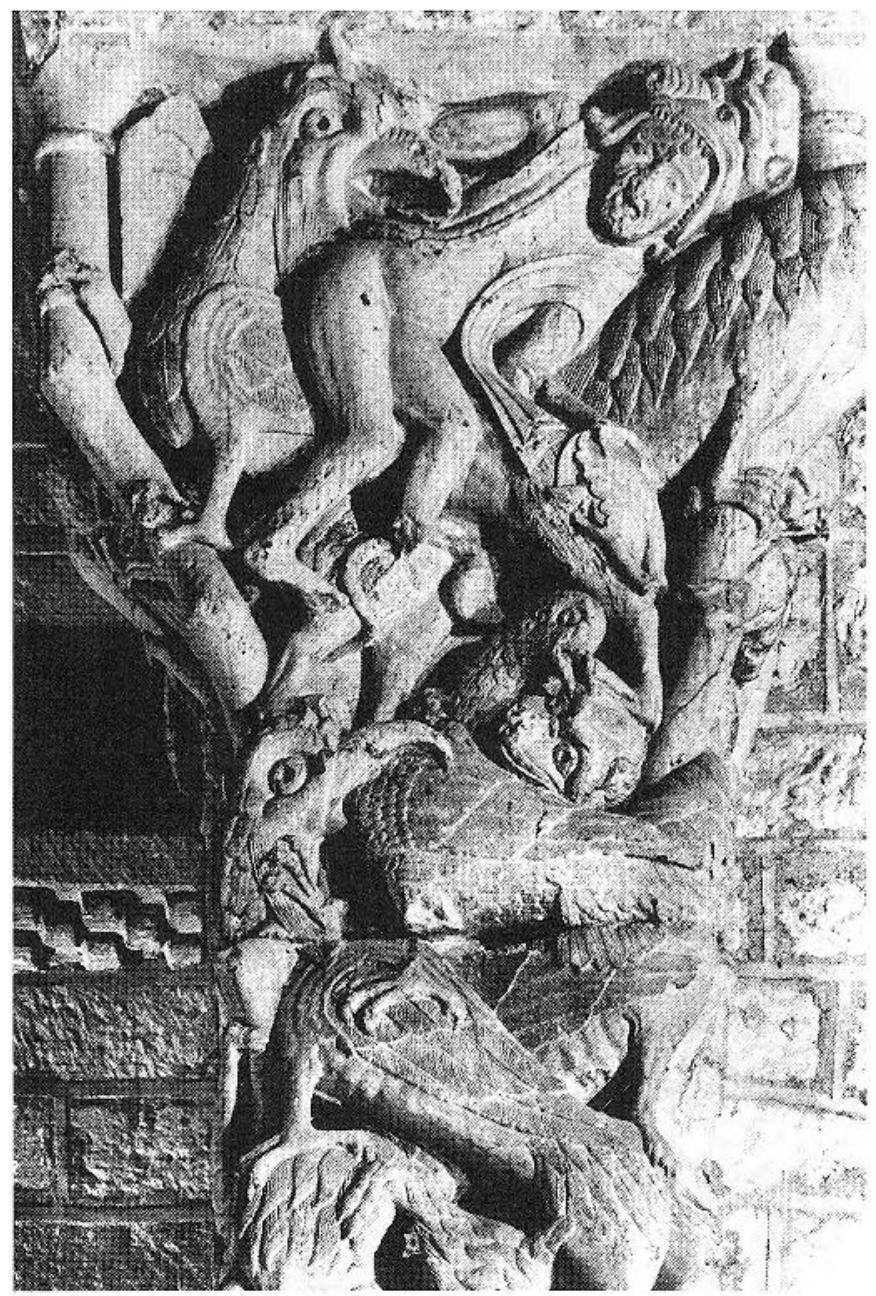

way, the pillar at Souillac constructs its meaning as well as its visual and psychological impact through the clash of these discourses.

\section{Discourses about Pain in the Romanesque Era}

The medieval historian, Georges Duby, has actually argued that the early feudal culture "does not appear to have been greatly concerned with physical suffering." Physical pain in this era, he contends, was rarely represented. To be sure, Duby is not suggesting that physical pain did not have an important presence in this society. Rather he is saying in discursive terms, "the way in which [physical pain] is perceived and the place which it is accorded within a value system are not unchanging facts." 20 Physical pain, he argues, has its own history. In this respect, the feudal period between the year 1000 and the early thirteenth century is very different from the later Middle Ages. In the Late Middle Ages one could say on many levels and in diverse 
practices in society that there is a definite cultivation of pain and suffering for positive values it could generate. In judicial practices one sees the development of the use of torture as a means for determining truth through confession of guilt. Religious devotional practices are transformed with a marked increase of affective piety, where people are encouraged to identify with the sufferings of Christ and the saints, exemplified in the realm of art by the introduction of new image types such as the Pietà and the Man of Sorrows. ${ }^{21}$ The early feudal culture, on the other hand, was much more resistant to the expression of pain. Such a contention might seem surprising, or at least highly ironic, given that this period has so often been characterized as one of almost unmitigated violence. With a dearth of centralized authority, power and wealth devolved to those who could wrest it by force. The anarchy of frequent private wars among feudal rivals, especially in the early feudal age, not only caused violence and death between knightly warriors, but an even more devastating pillage and rapine on lands of the unarmed peasants threatening their livelihood along with that of society as a whole. Thus, even the "normal" daily maintenance of this feudal society, with its ruling classes of secular warriors and the ecclesiastical establishment, was predicated on an extraction of surplus labour from servile peasants in exchange for protection from this violence along with the ever ready threat of force should the peasants fall out of line. ${ }^{22}$ Although monks were not supposed to be personally involved in such warrior violence, their institutions were involved, headed by abbots who were often lords of vast domains. To protect these properties from incursions of other warriors and to insure proper cultivation of lands by peasants, they often engaged lay vassals who were themselves given land benefices in return for this service. Violence was the mark of this epoch and social system, "at the deepest level of social structure and mentality." As Marc Bloch observed, "recourse to brutal gesture ... appears normal, even when right is not infringed." ${ }^{23}$ Yet, Duby argues, it is precisely the dominance of this "fundamentally male and military character of the ideology which prevailed at that time," one that "exalted ... male values of aggression and tenacious resistance to all attacks," which caused an under-valuation of physical pain. This ideology did not "allow any pity for physical failings," and viewed pain itself with disdain, along with those who called attention to their suffering. ${ }^{24}$ These beliefs find their highest expression and glorification, of course, in the literary tradition of the Chansons de Geste. Even in matters of judicial practice in this early feudal era, punishment for crimes committed by freeborn men were almost never penalized with corporeal punishment; instead they were ordered to pay fines. ${ }^{25}$

This warrior ethos was compounded by the Judeo-Christian tradition that saw pain entering into the world on account of man and woman's first sin. With their disobedience, Adam and Eve lost their comfortable Paradise and were forced to enter a world of pain and toil: To Eve God said, "in sorrow shalt thou bring forth children," and to Adam, "with labour and toil shalt thou eat" (Gen. 3. 16-17). This was a punishment inflicted by God that descended to all men and women. Duby pointed to the similarity of the Latin words for pain, dolor, and labour, labor, whose semantic relationship is highlighted in the Genesis text. In the feudal era, as was true in Greco-Roman culture, pain and manual labour were considered debasing, "particularly unworthy of free men," something relegated to women, serfs and lower-class criminals.

Of course, the Christian church warned that eternal pain as punishment for sin was a potential outcome for many on the Day of Judgement, a theme that appears to have been voiced by the church even more stridently and publicly than before when faced with the destructive forces of feudal violence they were having a hard time to control. ${ }^{26}$ Accordingly, Last Judgement imagery becomes more and more prevalent in visual art of the Romanesque era. Yet, it is curious, as Duby remarked, that even the figures of the damned suffering an inventive array of cruel torments in hell often seem to be totally impassive in the midst of their fate. Very different from the pain expressed in the face of the man at the top of the Souillac pillar, in the Last Judgement tympanum at Conques the lips of the damned are firmly tight and eyes stare out more in weary boredom than suffering pain (fig. 9). Pain, it seems for these sinners, is their natural plight; there is no longer any reason to resist. If pain is suggested here, it is by association. This is a prime example of what Elaine Scarry, noting the extreme difficulty inherent in any efforts to represent pain, calls the "recourse to a language of agency." Pain is signified by showing its external agent, the weapon, the means of torture that produces the pain. ${ }^{27}$ On the other hand, one could also say that the plethora of diverse punishments accorded here for particular kinds of sins, as well as for sinners in various stations of life, suggest a high level of didactic intent for this image. It is as much about teaching the nature of $\sin$ for the living, an effort to influence the comportment of the living, as it is an exercise in imagining or visualizing the pain of the damned in the afterlife. The real exertion and grimacing, the more emaciated and strained bodies, Jean-Claude Bonne has pointed out, are those of the tormenting demons, not the damned. The demons too have been condemned, but their condemnation is to one of perpetual manual labour, toiling in the labour of torture. ${ }^{28}$ This is another sign of the social negativity attached to manual labour the dominant ideology of this sociery maintained - like the lowly peasants, demons must work and suffer while they carry out these tasks for their Lord. One might even speculate that, far from experiencing horror, peasants who had occasion to look at this image might even have felt a certain glee - satisfied at the sight of royalty uncrowned and 
Figure 9. Conques, former abbey Church of Sainte-Foy. West Portal tympanum of the Last Judgement, first third of the twelfth century (Photo: author).

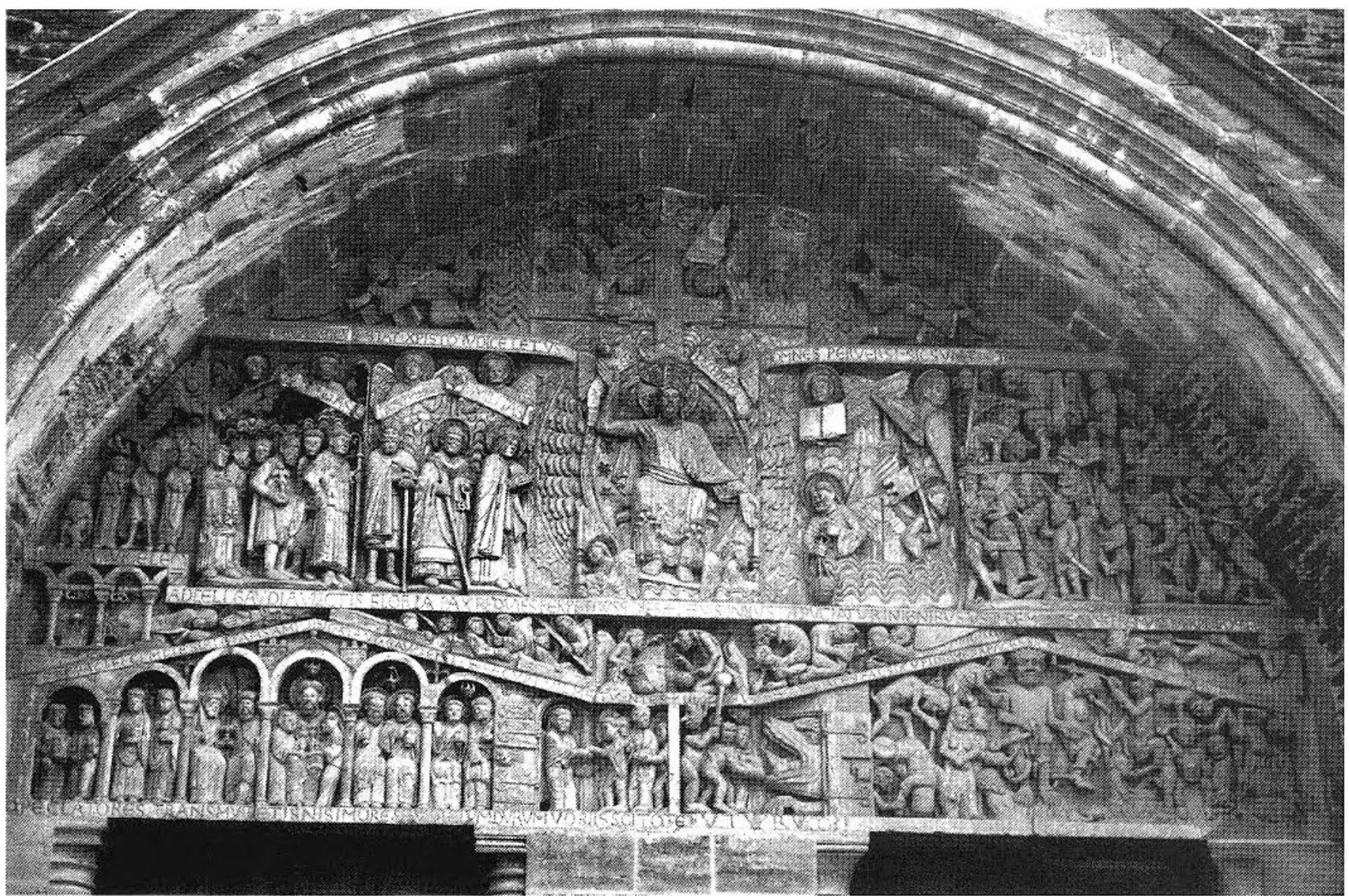

together with its entourage attacked by what looks like a carnivalesque group of peasant-like demons rising up in rebellion ${ }^{29}$ (fig. 9, middle register of hell, left side).

Certainly, the intent of the Conques Last Judgement tympanum was to present, with its graphically contrasting images, the promise that awaited those who were good and supported the church ${ }^{30}$ along with the threat of eternal punishment for sinners. Yet, when faced with an image such as this, if they paid attention at all, I would suggest that the warrior class could easily have thought it sufficient to pay the church institutions a fine from the profits of their booty through donations, rather than substantially change their aggressive warrior ethos. They could continue to war and pillage, and in spite of what the church may have said about particular abuses, especially when against them, all would have agreed that this warrior force was still necessary for the daily maintenance of the feudal society. When it came to using their military valour against foreign enemies, infidels and heretics, both the church and society with undivided heart could positively lionize their strengths.

What is so very different in the Souillac portal imagery is the way it pointedly focuses on individual human protagonists, not the grand schema of the divine plan, an impression, of course, enhanced by the lack of Christological focus. ${ }^{31}$ Yer, even had these sculptures been accompanied by a more traditional tympanum, the strategy that seems to lie behind the representations of the pillar and the relief is exceptional. This is because it was oriented much more towards actually changing the subjectivity of viewers who might not normally appreciate the value of humility and pain as a productive expression of inner spirituality. In this, the monastic patrons were espousing attitudes and practices that had long been part of their daily lives and spiritual quest, ones that were gaining an even higher profile in monastic life in the course of the twelfth century. ${ }^{32}$

For while he argued that the warrior ethos in feudal culture showed little concern for physical suffering, Georges Duby did allow that there was one sector in this society where pain and humility could acquire a positive value. This was in the monasteries (asylum poenitentium) where a life of penitential pain and prayer was willingly undertaken for the correction of sin and its expiation in hopes of final redemption, not only for oneself but 
also for one's fellow brothers and for patrons and familiars associated with the monastery. ${ }^{33}$ Fed daily on a diet of meditations on the glorious sufferings of Martyrs and on the moral lessons embedded in such texts as The Book of Job where the meaning of human suffering and physical pain is debated so directly - not to speak of the central icon of Christianity, the suffering Jesus Christ - these monks were continuing a tradition of Christian identity as a "community of sufferers" where discomfort and pain were accepted willingly for the purgation of souls. ${ }^{34}$ While dominant discourses in the Early Christian era focused on the hope of salvation, and the martyrs' stoic acceptance of violent death always remained a lustrous example, by the eleventh century the more current discourse circulated by the church was one of fear of death and, because the outcome was not assured, the need for perpetual vigilance and prayer. Moreover, the moment of death and the fear of it came more and more to be equated with excruciating pain visualized in metaphors of struggle, ambush or attack, escaped only by the fortunate few who were saintly or well prepared, for whom the moment of death was a blessed release. A prime illustration of this contrasting scenario is the didactic narrative image of Lazarus and the Rich Man, Dives in the porch relief at the left of the portal entrance onto the tower porch of the abbey church at Moissac (fig. 6). Here, the miserable life of painful suffering and humiliating rejection experienced by the leper, Lazarus, ends at the door of the rich man, Dives, who had spurned his plea for a few crumbs from his sumptuous table (upper left). While Lazarus' soul is whisked up by an angel and placed in the comfortable protective arms of Abraham (upper right), the rich man dies, and his soul is violently ripped out of his mouth by hideous demons and taken to a place of torment where his body is bent and crushed under the clawed feet of demons, his head pulled down and contorted by the very weight of his heavy money bag, the sign of his avarice (scenes just below the arches). ${ }^{35}$ It is in relation to this discourse of anxiety and fear about the moment of death and its consequences that the church, and in this era, monasteries in particular, garnered power, assumed social value and received donations. Fear of death, as we shall see, is the underlying message of the Souillac pillar, a message that, on one level at least, helped to call attention to the services for the dead offered there by the monks. Monasteries were not merely isolated havens of sanctity; they adopted an important social role by becoming institutions of communal intercession for society as a whole as well as for the brothers in their own communiry. Monks took on the responsibility to sacrifice themselves by living a life of purgatorial pain, and in this they would identify themselves with the figure of the poor suffering Lazarus, and a life of constant prayer for the benefit of others, while these others, as we saw with the warrior knights, could live out very different kinds of subjectivity so long as they supported the church. ${ }^{36}$ However, at Souillac, there is a greater effort to instil these monastic attitudes of penance and contrition in viewers of the portal. In the relief of Theophilus we do not see a stark contrast between innocence and evil as in the Moissac porch sculpture, but rather the acceptance that most people are sinners along with the provision of the means, penitence and prayer, through which every individual can personally seek redemption.

Pain in monasteries came in the form of physical deprivations from bodily comfort, including fasting as well as correctional flogging and self-inflicted scourging. Nor should one forget the pain involved in the long arduous hours spent standing and chanting the liturgy of the Divine Office where themes often included reflections on the sufferings of Christ or expressions of the fear of torment that might await souls after death and the future judgement. ${ }^{37}$ Although by the eleventh century it was rather overshadowed by the greater time spent in the liturgy, the Benedictine Rule also prescribed that monks should perform a certain amount of manual labour. ${ }^{38}$ The value of these actions, taken on by monks the majority of whom were from the same noble class as knights, must be seen as the obverse of the warrior ideology. Flogging, scourging, fasting, manual labour, all things the warrior class would avoid as totally unbefitting their status, are here undertaken to a large extent precisely because they contribute to a monk's humiliation. ${ }^{39}$ It is no accident that rituals of penance presuppose a servile subservience to authority (strict obedience) and include debasing confession and prostration. What is significant about the medieval monastic programme, Talal Asad has observed, is that its penitential discipline was not simply a form of correction and punishment, but also a "technique of self-correction ... [distancing the self from itself] to create a desire for obedience to the Law;" nevertheless, it was strictly enforced through observation by others (with corporal punishment if disobedience or nonconformity to the rules is perceived) and continually reinscribed in the practice of confession to authority. ${ }^{40}$ The closed society of monks, in this respect, was precursor to a major change in social mores that developed in the thirteenth century - a change from the military feudal ethos of a culture of shame (that opposes honour and shame and where one looked at one's peers for approval and a sense of one's worth) to a culture of guilt (when the practices of repentance and confession spread to the laity at large and where worth and individual value was established in relation to a higher authority). This general transformation, already nascent in the Souillac sculptures and soon to come about not long after they were produced, would lay the ground for the future development of the western subject and the modern state. ${ }^{41}$

Humility, which was a key virtue cultivated by Benedictine monastic discipline, is in total opposition to Pride, itself some- 
Figure 10 a. Fighting Knights: Detail from scenes of Roland in the Charlemagne Window. North Ambulatory of the Cathedral of Notre Dame, Chartres, ca. 1208-30 (Photo: reproduced from Colette Manhes-Deremble, Les vitraux narratives de la Cathédrale de Chartres, Paris, 1993).

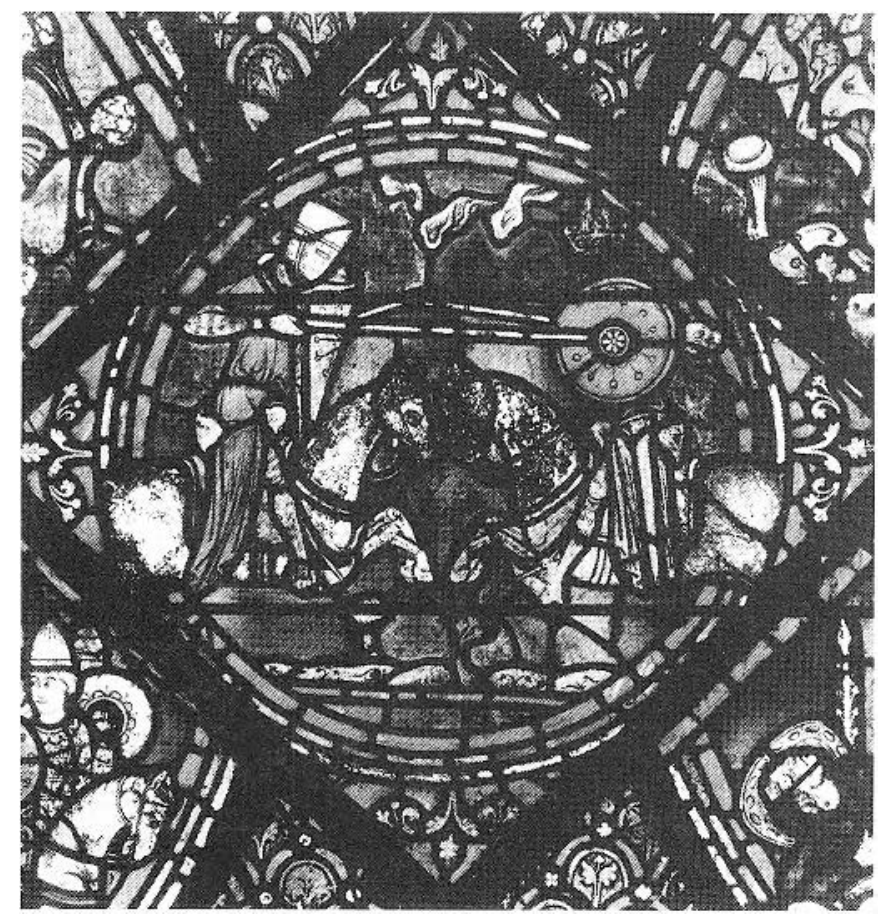

times personified as a mounted knight, as in the figure of the warrior at Conques toppled off his horse by demons and pulled into hell (fig. 9, just to the right of the gate of hell). This was the vice that was so often ascribed by ecclesiastics to members of the warrior class, especially when they destroyed church property. ${ }^{42}$ Monastic practices and conceptions can thus appear to be in complete opposition to that of the ideal knight. As a sign of the potential difference in subjectivity so often associated with these two social orders, one can just contrast the countless images of mounted warriors facing off in duel, equally as peers in combat, to those many portrayals of humble monks prostrate on their knees, in supplication or in offering, to a holy figure of higher authority $^{43}$ (fig. 10 a $\&$ b).

Just this sort of antithesis was highlighted in the Song of Roland when speaking about that paragon of warrior class cthos, Count Roland. Marvelling at Roland's furious return to battle against the Saracens after seeing so many Frenchmen dead around him, the narrator comments, "Never will any man be so bent on vengeance; Just as a stag flees before the hounds, So the Pagans take flight before Roland." [11.1872-75] Archbishop Turpin sees Roland's action as the perfect embodiment of a knight, and to express this clearly he pits his qualities in direct opposition to the profession of a monk:

\section{A knight should have such valour,}

Who bears arms and sits astride a good horse.

In battle he should be strong and fierce,
Figure 10 b. Prostrate Monks: Monks kissing the feet of St Edmund in Glory. Life of St Edmund, fol. 22v, ca. 1130 (Photo: Pierpont Morgan Library).

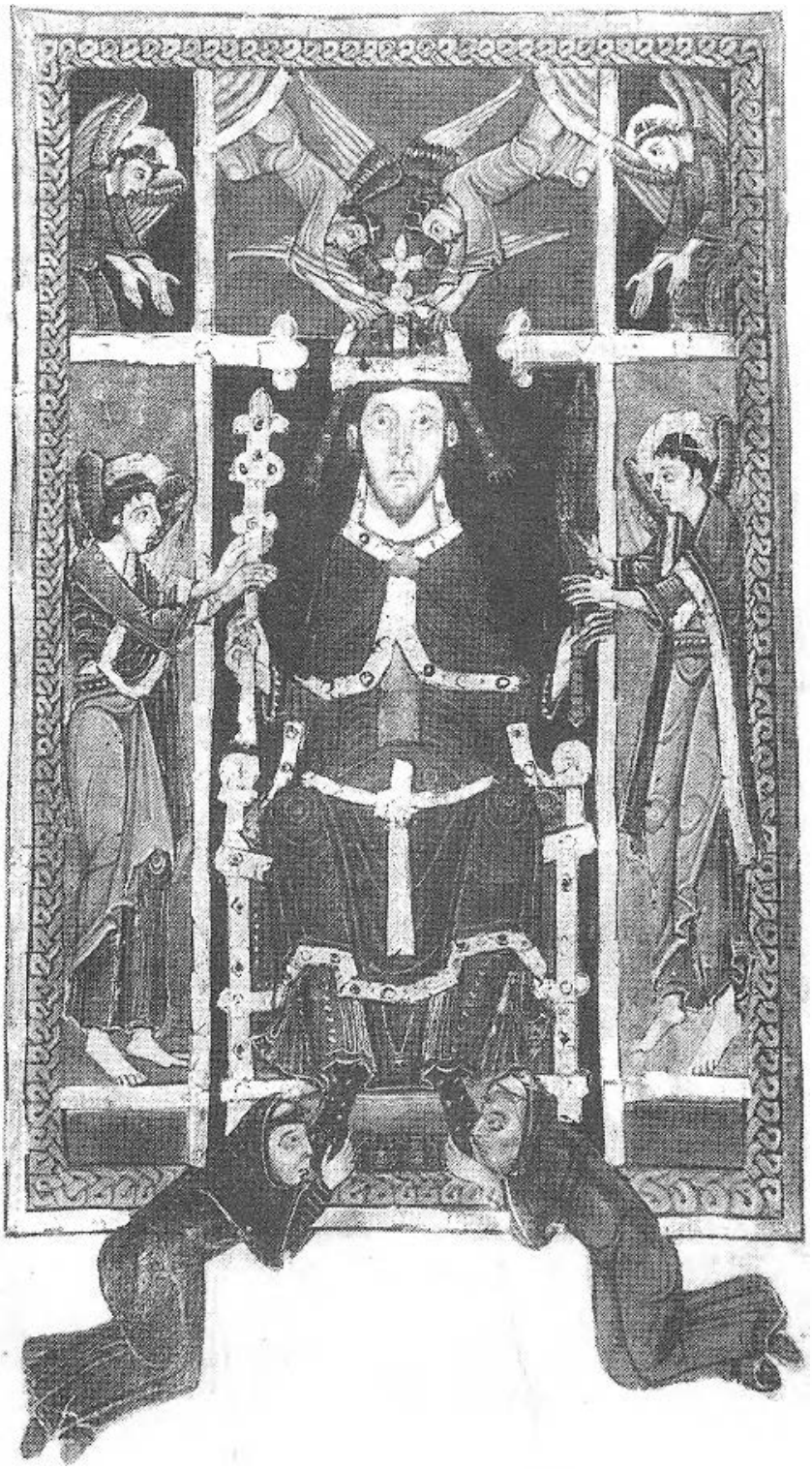

Or else he is not worth four pence.

He ought rather to be a monk in onc of those monasteries And pray all day long for our sins! [11. 1877-82 $]^{44}$

I do not mean to imply that monks themselves could not take on this warrior ethos associated with the knightly classes. They did do so, indeed, as the concept "Soldiers of Christ" implies. In this sense, the arena of heroic combat is transferred from the earthly to the spiritual realm, and the combat is a perpetual struggle against the Devil and $\sin .{ }^{45}$ Conversely, feudal warriors, when the sicuation was appropriate, at a cult site or when faced with death, could become more humble. In the 
Song of Roland, the mortally wounded hero went down on his knees to pray to God for his sins when he kncw death was quickly approaching. ${ }^{46}$ Still, the discourses on pain remain quite different within these two subjectivities, with the monks recognizing the value of subjection to pain (both mental and physical) as it cleanses the body of sin while the warrior would tend to deny it. What is exceptional in the Souillac sculptures is the way they work to force a reflection on the easy confidence of the heroic ethos. Let me now move to a closer consideration of the Souillac sculptures to demonstrate this striking intervention as they act to confront and in some ways meld these two very different subjectivities around the visualization of pain.

The Pillars at Souillac and the Visual Tradition of Heroic Beasts

What is important to recognize is just how strongly and pointedly the pillar evokes, but then subverts, a long-established tradition of heroic imagery of the sort that upholds the aggressive warrior ethos, which is so much a part of this feudal culture. This was an art of pomp and valour most often associated with masculine imperial, royal and noble circles, a tradition that can be traced as far back as Ancient Mesopotamia. The small pillar to the left of the portal (fig. 11) with its two lions converging on a ram evokes this tradition very clearly. It represents a single version of the beast attack motif that on the large pillar is repeated vertically four times.

Although the Souillac pillars represent particularly complex manipulations of the tradition, the stylized heraldic and antithetical postures together with the prevalence of animal imagery on the two pillar faces are hallmarks of what has been referred to as an "orientalizing" genre of imagery prevalent in the Near East, periodically fed into the West since ancient times. ${ }^{47}$ More recently, it was through the import of precious goods from Byzantium and Islamic territories where the tradition continued, especially in more decorative arts like silks and ivories, silver, gold and crystal vessels, that the influence of these styles entered into the formation of Romanesque art. Feudal lords from southern France for over a century had been exposed to opportunities to gain rich spoils from Islamic Spain when they participated in the wars of reconquest. They, in turn, would often donate some of these objects to churches and monasteries. Thus, it is through the context of church treasuries where the objects were more carefully guarded and handed down, that many of these originally secular works were preserved. ${ }^{48}$ The beast designs of the Souillac pillars have close stylistic affinities to ivories and silks produced in Islamic Spain, which were themselves often modelled on earlier Near Eastern Sassanian prototypes. ${ }^{49}$

Long before the twelfth century, the potential treasures of
Figure 11. Souillac, former monastic Church of Sainte-Marie. Crossed male and female lions attack a ram. Small Pillar to the left of the doonway on the west wall, ca. 1120-40 (Photo: A. Allemand).

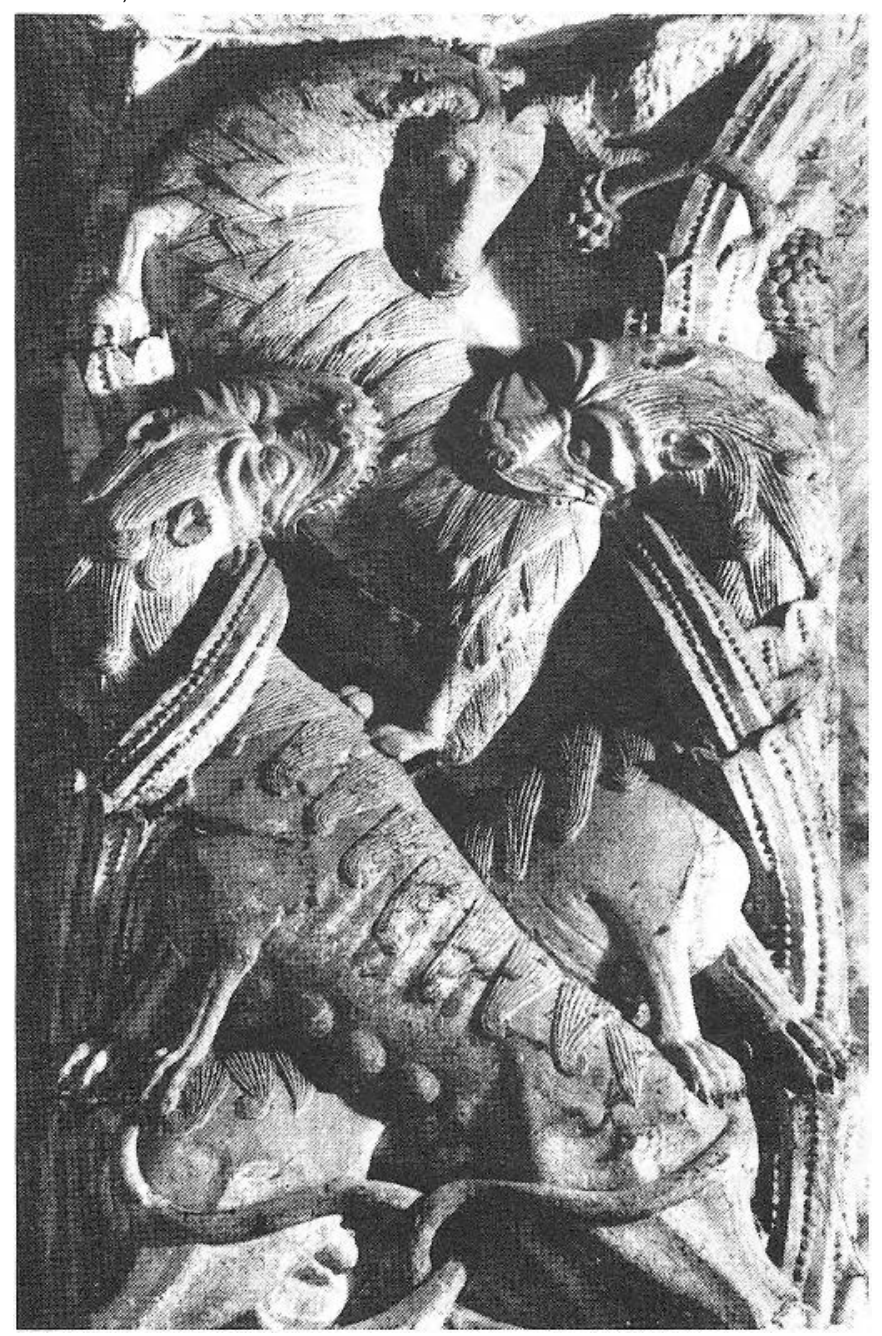

Islam had gained almost legendary status and were highly valued both in terms of their fabled wealth and their fine craftsmanship and design. It is in mythical proportions that they enter The Song of Roland, which opens with a description of a massive treasure that would be offered by the Saracen King Marsile to Charlemagne as a tribute to encourage him to take his army back to France. Nor only would hundreds of mules be laden with gold and silver, but exotic animals, bears, lions and camels together with trained hunting hounds and hawks in the thousands, were to be part of the offer. ${ }^{50}$ It is just this kind of display of animals and hunt that is so prevalent in the designs found on the precious silks, ivories and silver vessels that make up these treasures and were so popular with the warrior classes of all these regions, both Christian and Islamic. A good example of such cultural exchange is the popularity of carved ivory oliphants used by western feudal warriors in battle, for hunting and as drinking horns, and often donated to churches as gifts in the way that kings and emperors would donate crowns. ${ }^{51}$ These 
Figure 12 a and b. Oliphant. Italy, Salerno, ca. 1100 . Two views. Ivory, overall $68 \mathrm{~cm}$. Boston, Museum of Fine Arts, Maria Antoinette Evans Fund, 57.581 (Photos: Boston Museum of Fine Arts).

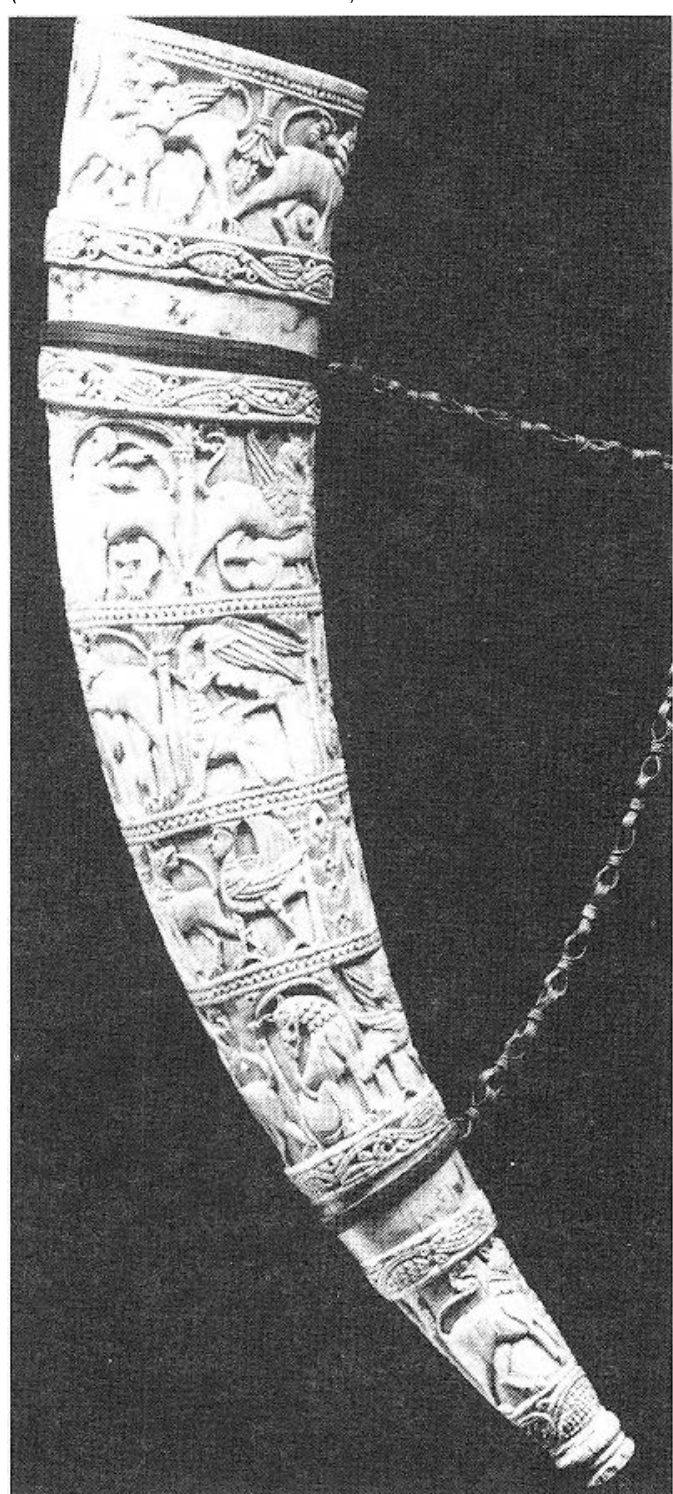

luxury horns were imported from Byzantium and Islamic influenced workshops in Southern Italy and Fatimid Egypt. Their imagery, like the fine eleventh-century oliphant now in the Boston Muscum of Fine Arts (fig. 12 a \& b), which includes images of lions and griffins attacking prey like those of Souillac, was typically filled with a display of animals including the exoric and the fantastic, somerimes with scenes of the hunt and other heroic deeds. ${ }^{52}$ Lions and griffins, predatory beasts par excellence, had long been mainstays of this visual repertoire and soon became favoured animals in the growing art of heraldry. The basic theme in imagery of this sort revolves around the concept of predatory beast attack (or its potential) to which the prowess of male human protagonists is compared, either directly in the image or by inference.

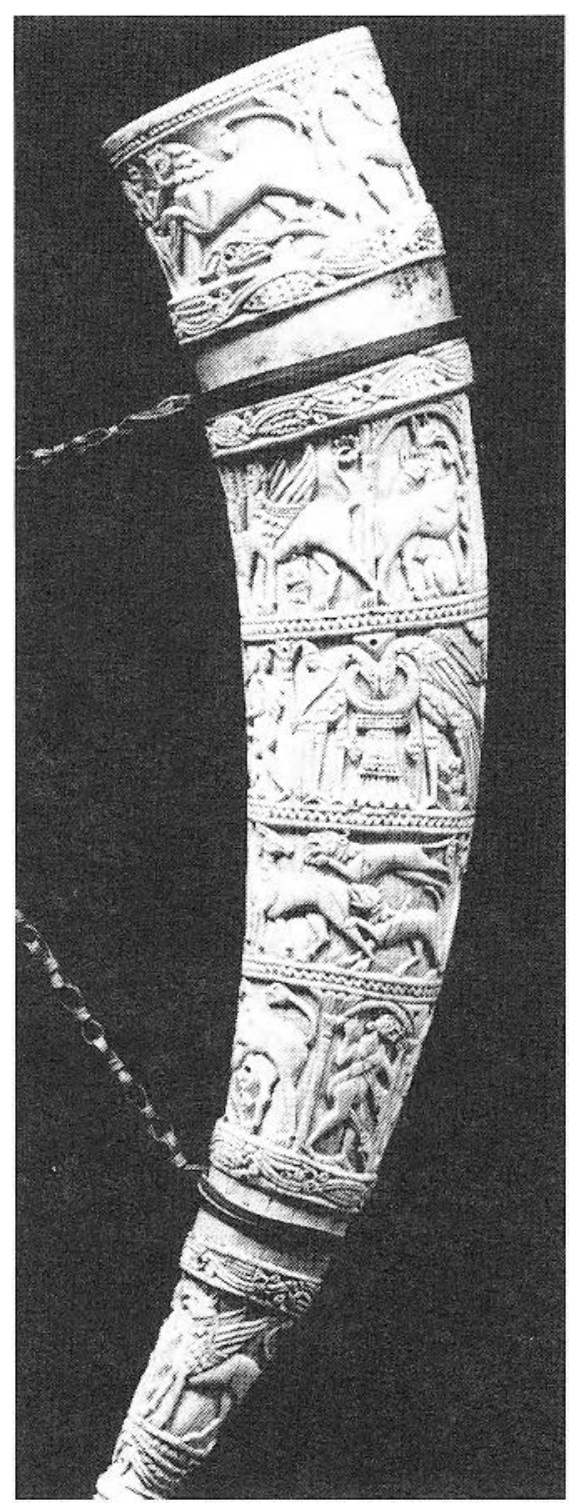

An interesting object to compare with the pillar imagery at Souillac is the eleventh-century Islamic ivory casket that came into the hands of the monks of the Abbey of Silos in Spain (fig. 13). In the twelfth century, whether because of damage or by intent, some of the panels were replaced with Limoges-style enamel plaques, including one of Santo Domingo, patron saint of the abbey, and the box came to be used as a reliquary. ${ }^{53}$ What is interesting is the way that the Islamic ivories of princely secular origin have been preserved in a Christian context. ${ }^{54}$ Looking at the carved imagery of animal and hunt scenes on the rectangular face of the Islamic ivory, one can see the kind of visual vocabulary that is being reworked in the pillars at Souillac. The Silos casket, however, like the ivory horns, represents a positive heroic scene - a quasi-mythical stylized image of the 
Figure 13 a and b. Islamic ivory casket transformed into a reliquary for the Monastery of Santo Domingo de Silos. View of the back and detail. Ivory casket: Cuenca, 1026; mounts: ca. 1150-75. Ivory and wood, with gilt-copper and champlevé enamel mounts, $19 \times 34 \times 21 \mathrm{~cm}$. Burgos, Museo de Burgos (106) (Photos: reproduced from The Art of Medieval Spain, A. D. 500-1200, exh. cat., The Metropolitan Museum of Art, New York, 1993).

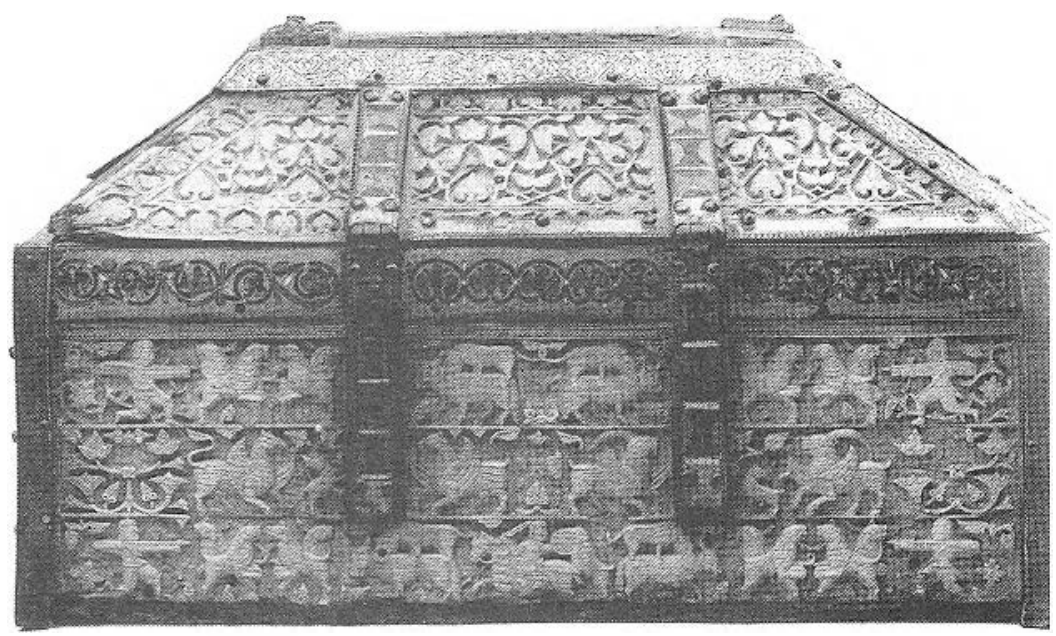

ivory formally highlight the sense of conflict in an attacking melee while archers aim their arrows from the sides. In the middle register griffins and winged ibexes parade in a display of abstract strength. To increase the sense of danger to the human protagonists and consequently their valour, the casket employs the common device of including accompanying scenes of lions attacking and dominating other victims. ${ }^{56}$ By contrast, the horseman at the centre of the bottom register, in direct confrontation with a lion, valiantly fends him off.

On the large pillar at Souillac we see a similar stylized coupling of the crossed bodies of aggressive beasts, but here they are set one on top of

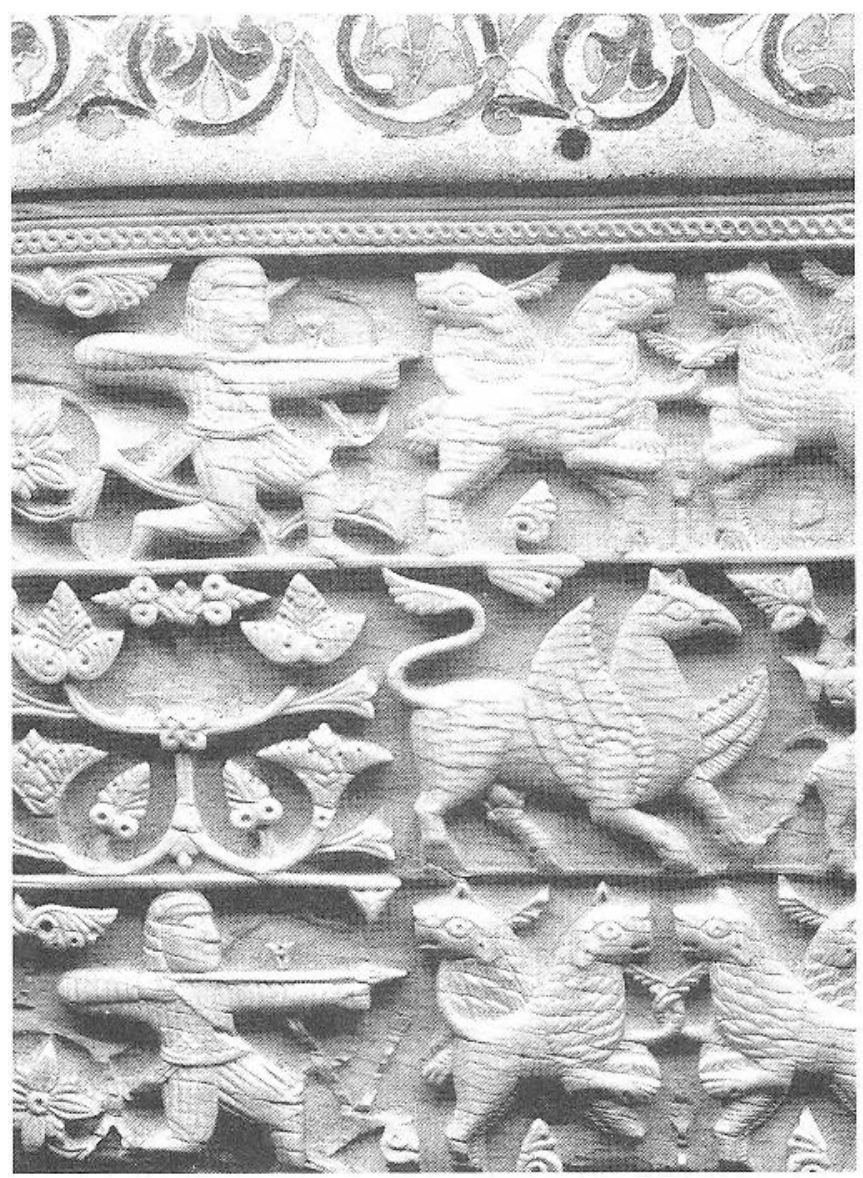

manly hunts which in warrior cultures and amongst ancient royalty were not only popular pastimes, but were ones that highlighted the kind of prowess necessary in military battle against enemies, a kind of representation these high-class warriors liked to sec as an ideal reflection of themselves. ${ }^{55}$ The crossed bodies of the leaping lions grouped in pairs horizontally on the each other in the narrow vertical ficld. The entwined tails of the paired lions on the small pillar are sure indication of the ultimately Near Eastern origin of the stylistic models. On the large pillar, however, rather than a bold hero fending off the animals, the Souillac man is vulnerable and in pain, his body naked and attacked. He is not the courageous hunter or slayer of dangerous beasts, but instead, just like the animals below, he has become one of the hunted himself, with no energy even to fight back. ${ }^{57}$ This is all the more disturbing because it is so very rare to find human victims directly represented within the heroic tradition of animal imagery to which the style of the Souillac pillars alludes. In the pillar representations an audience imbued with the warrior ethos has been specifically called forth, but the expectations of seeing and identifying with an heroic image have been subverted to produce instead a problematic image of weakness and defeat, all the more powerful and anxiety-producing because of this contrast.

Ferocious Beasts and the Identity of Noble Warriors and Rulers

It was as if there were two very ferocious lions, one of whom had found a deer first. It lets its pitiless eyes roam over the animal it has knocked to the ground. And in order to stir up the eagerness of the belly with more intense provocations it holds back the first bites, clinging to the entrails and opening its jaws very savagely, quite as if a headlong descent into slaughter would ruin its satiety. And when the lion soon flexes its claws to rend the gentle animal to pieces with all its strength, by chance it is threatened by the other lion's arrival. While they strugglc, now not for booty but for their lives, the deer slips away unharmed. ${ }^{58}$

It is with this simile of savage devouring lions that Bernard of Angers, eleventh-century author of The Miracles of Sainte Foy, 
Figure 14. Coronation Mantle of Roger II, ca. I133-34. Silk with gold embroidery, $1.4 \times 3.4 \mathrm{~m}$. Vienna, Kunsthistorisches Museum (Photo: Kunsthistorisches Museum, A-1010 Wien I).

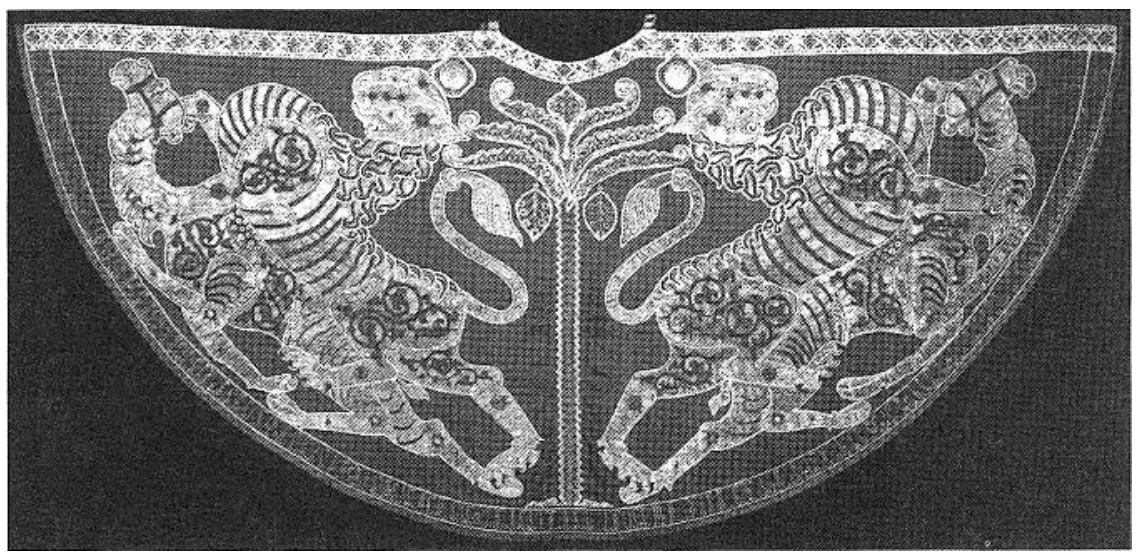

practice of using beasts of prey as protectors and potential threat in the more ceremonial presentations of royal display. In France, the old tradition of incorporating bodies and heads of lions into the design of thrones of rulers and kings was maintained. ${ }^{61}$ The effect was such that it would appear the ruler was sitting on the backs of lions. The lions, standing at attention, their visages forever growling, are there to protect the ruler from any unwanted aggressor. They stand as a symbol of the potential power of the ruler.

Another ceremonial piece is the magdescribes two enemy bands of warring knights who had been distracted from their prey because of their own mutual hatred. Bernard was telling the story of Peter, a noble lay abbot, who, returning from a pilgrimage to Sainte Foy at Conques, had been spied by two different groups of warriors, both intent on ambushing him. But when the knights saw each other, since they too were enemies, they forgot Peter and proceeded into a vicious melee "tearing themselves to pieces in mutual slaughter." Bernard, of course, attributed Peter's salvation to the protective forces of Sainte Foy.

The story paints a vivid picture of the violence of the times. What also comes to notice is the way Bernard so easily and evocatively found it appropriate to compare these fighting knights to ferocious bcasts of prey. Although he was critical of this violence, there is no doubt that he was sensitive to the awe and majesty of such animal ferocity. His descriptive imagination brings to life, and may very well have been inspired by, the countless representations of rapacious beasts so prevalent in the artistic tradition of heroic imagery described above. It is an awe and majesty that is still present in the Souillac pillars in spite of the humiliating reversal suffered by the human protagonist.

For it was a common topos in medieval discourse to equate the noble warrior with ferocious animals, just as the Franks in The Song of Roland were said to be "as fierce as lions" and the Saracen army fled from Roland like "stags running from hounds." ${ }^{59}$ This class identified itself with these majestic beasts of prey as much as others saw them in this light. Recognizing this delight in aggressive force and heroic combat, it was natural for the artist monk Theophilus, in his twelfth-century treatise, On Diverse Arts, to recommend imagery of this sort for works destined for this class. Decorated silver, he suggested, might include griffins and lions fighting by themselves or each one strangling a sheep along with other images of fighting heroes: knights fighting dragons and Samson or David fighting lions. ${ }^{60}$

This association of the feudal warrior class with preying animals in the midst of their attack is related to the even older nificent Coronation Mantle of Roger II, made for this warrior and ruthless statesman, who in 1130 managed to force the antipope Anacletus II to crown him King of Sicily (fig. 14). The cape, probably made by Islamic artists, is almost contemporary with the Souillac sculptures. With it Roger wrapped himself in the representational power of lions attacking camels, possibly even a reference to his desire to conquer Africa. The mantle also makes ingenious use of the Tree of Life device. Here Roger is equated with the Tree of Life that is protected by the lions. It was a defiant statement against the many enemies who continued to dispute his reign.

It is just this sort of aggressive protective function that the heroic imagery of the crossed lions serves on the trumeau of the portal of the abbey church of Moissac (fig. 3). They are in tune with this heroic feudal identity, a perfect positive support for the triumphant Christ King enthroned in the tympanum above. ${ }^{62}$ The Moissac trumeau has often been cited as the model for the pillars at Souillac. Its crossed male and female lions with intertwined tails find a close counterpart in the paired lions of the small pillar at Souillac, while the vertical stacking of the crossed bodies is similar in concept to the large pillar. What is more interesting but not usually recognized, given these similarities, is just how different the two representations are with respect to their over-all significance, their function and their potential effect on viewers' subject positions. While the Moissac lions' protective and heraldic stance are fully in line with the accustomed identification of feudal warriors and rulers with the aggressive power of ferocious beasts, the Souillac pillar, with its focus on the defenceless body of the human figure, works to undermine that very heroic tradition, greatly altering as well as expanding meanings that could be apprehended.

While King Roger's body would have been marvellously clothed in his mantle of animal power and majestically seated on his throne, the man at the top of the Souillac pillar sits dangerously naked, his body not protected by these animals but devoured. 
What is striking about the Souillac pillar is the way it works on this feudal identity of the warrior ethos. Although ultimately the moral and spiritual lessons might be similar, the pillar imagery works differently from the more straightforward didactic representations like that seen in the Last Judgement tympanum at Conques. Laity, leaving the geographic sites where their subjectivity reigned (for the dominant warrior class that would be the hunt, the battle field, the castle hall, etc.), entering the cultural space dominated by monks and approaching the church, would probably expect to encounter moralizing religious messages or portrayals of God's glory. What might not be expected, especially for a knight going into a place that is very different from his normal sense of being, would be to encounter these images of ferocious beasts portrayed in the heroic style with which he (and all sociery could participate in this identification) is very familiar and accustomed to identify. With his anticipation of pleasure at seeing this familiar animal imagery heightened, that pleasure is dramatically thwarted when the viewer realizes that the image contradicts his expectation and actually threatens his concept of the heroic body. ${ }^{63}$ Seeing the human victim, singled out at the top of the column, not triumphant, not defending himself, but crushed under the impost block, locked in the grasp of the beasts, threatened and devoured by the very signifier with which he normally identifies (aggressive strength of wild beasts = heroic valour of knight), would certainly be cause for anxiety. The representation shortcircuits his former love of associating himself with ferocious beasts, while forcing him to consider identification with this decidedly unheroic figure suffering torment of animal attack. Seeing this, the heroic subject will feel shame. With shame comes doubt and lack of confidence. The armour of the warrior ethos is shattered. Now this viewer will begin to feel pain.

Identification and Reversal: Towards a Feeling of Pain and the Fear of Death

But all is not lost; an opening has occurred out of which a new subjectivity might grow. The monks have known for a long time that pain is productive; it has value. This is the message they would like to get across. The sculpture's shattering of the warrior ethos primes the audience for a new lesson, one that might produce a shift in consciousness. The loss of confidence of the heroic subject might now lead to the questioning of other certainties. The point of this image is to make viewers uncomfortable and think about the meaning of Death - not deny it with bravado, as was the custom. ${ }^{64}$

It is through these cracks in the broken heroic tradition that viewers at Souillac might have begun to see the pillar imagery from a monastic point of view, realizing that part of the ambivalence in this image is because it contains visual clues from religious iconography as well as the secular heroic. The Souillac figure has a shroud around his neck; he is naked like the dead and those who rise from the dead at the end of time for Judgement. But he is not confident. His body is not only the anguished body of a man in pain; it is also the contorted body of the sinner whose flesh is attacked by beasts because it smells of vice. Although this is no traditional image of a damned soul in hell, viewers looking more closely at this suffering figure would begin to consider his plight, forced to ask, "What does it mean to be defenceless in the face of Death?"65

With this warrior's confidence shaken, viewers will more readily see this image from the perspective of a religious discourse and be jolted into taking the lessons more sincerely to heart. The visual transposition of the heroic mode would have been effective for any viewer, lay or monastic. Moreover, even within a religious discourse and religious traditions of imagery, at the very basic level that any Christian would understand, the man attacked by beasts at the top of the pillar remains a disturbing figure. Like the antithetical nature of the pillar design itself, the suffering body at the top is not just directly meaningful itself (i.e. it is not simply someone damned in hell), but takes on a range of unsettling meanings as it stands in opposition to a number of positive exemplars. Just as this representation presents a reversal of traditional secular heroic imagery, it also calls to mind, but then reverses, key motifs in religious iconography. Visually the figure at the top of the Souillac pillar is reminiscent of portrayals of Daniel in the Lions' Den (fig. 15), ${ }^{66}$ yet it transposes this well-known scene into its opposite. Whereas the hungry lions in the pit do not harm Daniel, confident in prayer, the Souillac figure is ferociously attacked. Thus, for the viewer, the pillar imagery gains meaning by virtue of this thematic reversal. ${ }^{67}$

Looking at the man at the top of the Souillac pillar, one sees that this is no Daniel, confident even as he is thrown into a den of lions. Daniel had always obeyed God; in the den he had faith and prayed for deliverance. Daniel was in a pit of hell, but was not attacked - not judged by the lions of justice and found wanting, guilty of sin. Daniel had the armour of prayer and goodness that the lions could not permeate. Note that the lions portrayed in the Moissac capital of Daniel in the Lions' Den have a similar addorsed stance, but these are now peaceful lions made tame and protective of the Tree of Life. Daniel would indeed be brought back from potential death to life. But the future of our Souillac figure is in doubt. His body is not the clean-smelling, fresh body of the saint, but instead the odorous one, the body weak with fear and pain, the kind that will immediately attract predacious beasts.

For Christians, Daniel had always been a sign of hope for God's grace; they took comfort in the knowledge that God would protect the faithful in the way he protected Daniel in the 
Figure 15. Moissac, former abbey cloister. Capital of Daniel in the Lions' Den, ca. 1100 (Photo: Images du Patrimoine, Midi-Pyrénees).

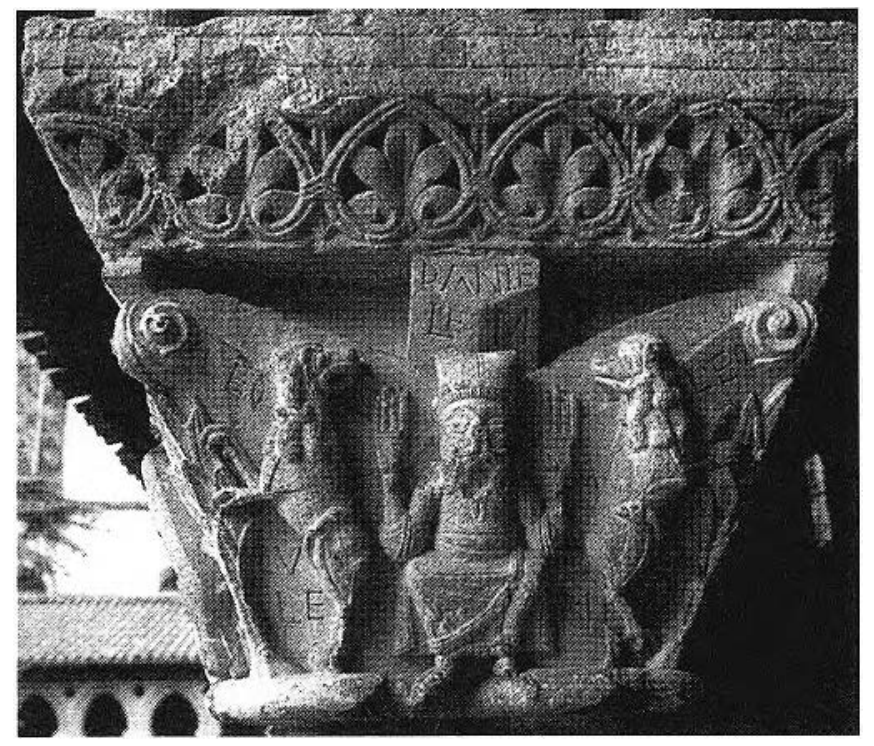

Lions' Den. For centuries Daniel had been cited in prayers for the agony of the dying and for burial, the Commendatio Animae, and was illustrated in some of the earliest Christian imagery of the Catacombs in Rome. ${ }^{68}$ Even the heroic Roland saw fit to cite Daniel in the dramatic scene of his contrition and prayer to God when he knew he was about to die. ${ }^{69}$

Contrasting with this positive model of redemption, where the good servant of God, Daniel, is assured escape from death and the hell that the pit signifies as a reward for his faith, the Souillac figure is faltering, a more potent reminder that not all are saints and that most people will have to work hard for such salvation. The image is intended to shake viewers out of any complacency they may have felt in this respect.

The Souillac man attacked by beasts is, thus, clearly a sinner, in that he is representative of "Fallen Man" after the original sin of Adam. He certainly is no Adam in Paradise at peace with the beasts before the Fall as was represented on an Early Christian ivory diptych now in the Bargello (fig. 16). Compared to this, any viewer would be forced to conclude that the Souillac man is a sinner about to lose Paradise. An effect this image was intended to produce was the creation of fear about death and its potential pain and violence, something that this pillar could do particularly well, by virtue of its form, for an audience not normally receptive to this idea.

Thus, one could conclude that a key message of this pillar image, promoted by the monastic establishment and highly effective when directed to a secular audience dominated by warriors, is that to be a great warrior, to win many battles on earth, to strike down one's enemies here, is good and even of great value to monasteries when they act in support - but it is not enough in face of ultimate battles in the afterlife if a person
Figure 16. Adam in the Garden of Eden. Ivory Diptych Panel, fourth century. Florence, Bargello Museum (Photo: reproduced from Danielle Gaborit-Chopin, Ivoires du Moyen Age, Fribourg, 1978).

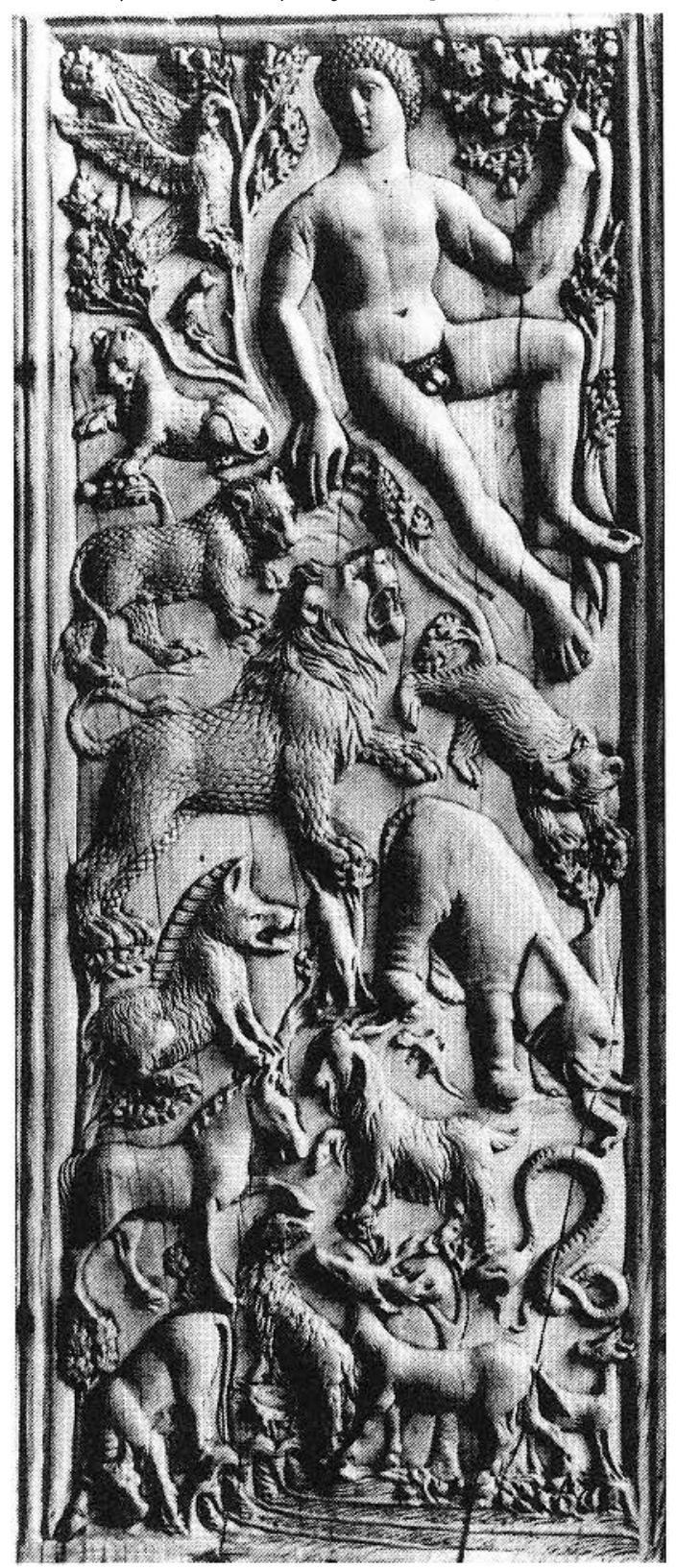

is consigned to hell. There, physical prowess, bodily strength, resistance to pain will not work. The figure will be caught, much like the man on the pillar, unless he prepares. He must patronize this sanctuary, dedicated to the Virgin who is especially merciful toward sinners, and seek the aid of Souillac monks as intercessors. The large sculptures of the formally seated abbot and St Peter flanking the Theophilus relief are there to remind viewers of the authority of the ecclesiastical establishment and its power to absolve and excommunicate. ${ }^{70}$ However, this will only work if the individual sheds his warrior 
pride and approaches with the subjectivity of a monk, humble in prayer. This is exactly the action that is viewed in the Theophilus narrative on the main relief above the portal at Souillac (fig. 5).

The Conversion of the Heroic Identity: The Man Attacked by Beasts as Counterpoint to Other Sculptures at Souillac

The restorative actions of penitential humility and prayer are directly narrated in the story of Theophilus in the relief above the portal at Souillac. What is more, Theophilus is dressed like a nobleman, not a cleric as became the tradition in so many later representations. Theophilus was a grave sinner who denied God (the essence of all sin) and sold his soul to the Devil, a sinner like the man on the front face of the Souillac pillar, but not like the ever-obedient servant of God, Abraham, and his innocent son Isaac portrayed on the pillar's left side. In exchange for help, Theophilus agreed to submit to the Devil and even to write his abnegation of God in a signed contract. This deed is represented through that quintessentially feudal ritual act - the rite of homage. On bended knee, Theophilus places his hands in those of the Devil, taking him as his lord and becoming his vassal. Not only has Theophilus committed the Christian sin of abnegation, but he has also broken the most sacred trust of the feudal vassal - loyalty to his true Lord. Thus, we see again how the Souillac sculptures are targeting this feudal audience.

While Abraham is the positive model of faith and obedience much like Daniel, Theophilus, no biblical hero, must agonize and suffer in prayer and fasting for a full forty days before his redemption. Consequently, he goes to pray at a chapel dedicated to the Virgin, hoping that she will help. The agony of his remorse and fear of judgement, described at length in the major literary texts, ${ }^{71}$ would not be visible if we did not have the parallel visualization of fear, pain and threat depicted on the Souillac pillar, metaphorically embodied in the man attacked by beasts. In the relief, the Virgin heard his prayer and, together with an angel, miraculously brought back the damning contract to the exhausted Theophilus, fallen asleep but still kneeling in his penitential posture before the church portal. Theophilus could now die in peace with hopes of avoiding the violent death portrayed on the pillar. ${ }^{72}$

While Theophilus is narratively fixed in his penitential posture at the moment when the bond is miraculously returned, signalling his redemption and the means through which he gained it, the plight of the suffering man on the pillar remains precarious. Yet, there is something curious about the way all the figures are locked into a sort of suspended animation. Even though the Souillac man is slipping and the animal prey below are heading downwards, they are actually kept from falling by the very beasts that attack them. Perhaps there is a message here; as we have been arguing, the monks would insist that there is a value in this perpetual re-enactment of pain.

From a monastic perspective, the pain that is enacted on the Souillac pillar is not just the threat of torment for sinners but also its antidote, the mental anguish, visualized in metaphors of physical pain, that enters into all true forms of penitential prayer. Embedded in the Souillac pillar, I contend, is a call to prayer, an insistence on the need for prayer in the face of death along with its visualization. We saw how the reworking of the visual language of the Near Eastern beast tradition functioned well to dramatically call attention to the threatened dying body. Penitential prayer, we are reminded in the Souillac relief, is what saved Theophilus from his grave sin. Moreover, prayer in the face of Death is highlighted unusually in the Souillac rendition of the Sacrifice of Isaac (fig. 7 a), since Isaac holds his hands in prayer while the Angel swoops down with the ram to save him, just like the Angel carrying the Virgin to the penitent Theophilus. Consonant with the prayer that Theophilus enacts on the relief, the front face of the pillar could represent the actual plaint of prayer, including the fear of death and the pain and anguish that should accompany true contrition - something the monks knew well and carried out daily for themselves and their patrons. Indeed, in contradistinction to the typical secular viewer of the pillar who would more likely identify with the warrior ethos and be very disturbed by the unheroic suffering figure, the monk, because of all his training and daily practice of penitential prayer, could readily identify with the threatened body of the nude man attacked by beasts. As with Christ himself, who was attacked, mocked, tormented and killed, but still rose from the dead, monks believed that purgatorial pains of this kind were beneficial. In their liturgy for the dead and dying, monks would even dramatize the pleas of those who face death, chanting, "Deliver me from the mouth of the lion," and thinking of Christ's death on the cross, they would pray, "When you will come to judge, deliver from death the souls of those whom you redeemed. Deliver not up to beasts the souls that confess you." 73 As a plaint of prayer, now that the pillar has made an opening for the readjustment of the feudal heroic subjectivity many in the audience had maintained, the heroic elements on the pillar take on a slightly different meaning. The Souillac man and his viewers have learned to begin a process that will, as with the martyrs of old who were willingly torn by beasts, though crushed through pain and humiliation, be a path toward a final triumph in the afterlife. These beasts in their vicious attack on the body and consciousness of this sinner have produced a new notion of pain for the secular viewer, making the viewer internalize the agony, by externalizing the pain on the body in representation. In that way it begins the process of the purgation of sin while encouraging them to seek help from those specialists in intercession - the monks and the 
Virgin at Souillac. The monks, this time identifying with the ferocious beasts, might well feel triumphant that they had managed to wrestle a new subjectivity and possibly new patrons out of their well-healed secular audience. The sculptures stand as a perpetual lesson on the need to fear death and on the value of prayer and humility, and even stand as an everlasting enactment of that very prayer. What better way to decorate a portal that is situated directly above a burial crype? ${ }^{74}$

What is more, as I have attempted to analyse them here, the Souillac sculptures provide us with an interesting glimpse onto the mechanisms by which visual productions might have contributed to the early stages of major alterations in mentality that would occur by the thirteenth century as society was transformed from a culture of shame to one of guilt, from a society that denies pain to one that sees its value.

\section{Acknowledgements}

Ideas for this article on the Souillac Pillar and the visualization of pain were first presented in the session, "Pain and Imagination in Medieval Art," originally organized by Glen Peers and sponsored by the International Center for Medieval Art at the $5^{\text {th }}$ Annual International Medieval Congress, Leeds, England, in July 1998. I would like to thank ICMA and the Samuel H. Kress Foundation for funding that allowed me to attend this conference. My thanks go as well to my colleagues, Rose Marie San Juan and Katherine Hacker, for comments they provided on this earlier paper and a special thanks to Rose Marie San Juan for her reading and commentary on the article. Jim Bugslag receives my appreciation for his helpful editorial comments.

\section{Notes}

1 Andreas Petzold, Romanesque Art (New York, 1995), 162.

2 Michacl Camille, "Mouths and Meaning: Towards an Anti-Iconography of Medieval Art," Iconography at the Crossroads, ed. Brendan Cassidy (Princeton, 1993), 43-58.

3 Meyer Schapiro, "The Sculptures of Souillac," Romanesque Art, (1939; repr. New York, 1977), 102-130, esp. 123.

4 R.W. Southern, The Making of the Middle Ages (New Haven and London, 1953); H.E.J. Cowdrey, The Cluniacs and the Gregorian Reform (Oxford, 1970).

5 Gcorges Duby, The Three Orders, trans. Arthur Goldhammer (Chicago, 1980). This was the concept of the Three Estates that in France would last until the French Revolution despite its anachronisms. Duby has situated its earliest full expression in the third decade of the clcventh century. One kcy quote is from a poem of Adalbcro, bishop of Laon, translated by Duby as follows: "Triple then is the house of God which is thought to bc one: on Earth, some pray [orant], others fight [pugnant], still others work [laborant]; which three are joined together and may not bc torn asunder; so that on the function [officium] of each the works [operal of the others rest, each in turn assisting all." Duby, The Three Orders, 5. This is, of coursc, an idcalized concept of an otherwise often conflictual socicty, onc Duby has shown could serve a range of economic, political and cultural interests.

6 Calvin B. Kendall has cxplored precisely this point in his recent book, The Allegory of the Church: Romanesque Portals and Their Verse Inscriptions (Toronto, 1998). My analysis of the Souillac sculptures conforms with Kendall's gencral vicw supported by evidencc from inscriptions that the Romanesque portals often functioned as a locus of transformation and transcendence, calling on the worshipper to repudiate sin and the mundane in order to be elevated into a temporary state of grace within the sacred space of the church defined as a prefiguration of possible futurc salvation.

7 This is the title used in the culminating chapter of M.F. Hearn's, Romanesque Sculpture: The Revival of Monumental Stone Sculpture in the Eleventh and Twelfth Centuries (Ithaca and Ncw York, 1981).

8 Giles Constable, The Reformation of the Twelfth Century (New York, 1996). The period is sometimes referred to as the "Crisis of Monasticism:" Jean I eclercq, "La Crise du monachisme aux XIe ct XIIe siècles," Bulletino dell'instituto storico italiano per il medio evo e archivio Muratoriano, 70 (1958), 19-41.

9 For a full discussion of Bernard's critical remarks, sce Conrad Rudolph, The "Things of Greater Importance": Bernard of Clairvaux's "Apologia" and the Medieval Attitude Toward Art (Philadelphia, 1990).

10 One of the most dramatic cases is the Abbey of Vézelay with its history of conflict with townspeople, count and bishop. See Barbara Abou-El-Haj, "The Audiences for the Medicval Cult of Saints," Gesta, 30 (1991) 3-15. Also the dissertations of Judy Scott Feldman, "The Narthex Portal at Vézelay: Art and Monastic Self-Image," Ph.D. diss., The University of Texas at Austin, 1986 and Kristin M. Sazama, "The Assertion of Monastic Spiritual and Temporal Authority in the Romanesque Sculpture of Sainte-Madeleine at Vézelay," Ph.D. diss., Northwestern University, 1995. For Moissac and Beaulieu see Peter K. Klcin, "Programmes eschatologiques, fonction ct réception historiques des portails du XIle s. : MoissacBeaulieu-Saint-Denis," Cahiers de civilisation médiévale, XXXIII (October-December 1990) 317-349.

11 The most recent studies that have addressed this question have both appeared in the journal Gesta: Jacques Thirion, "Observations sur les fragments sculptés du portail dc Souillac," Gesta, XV/ 1-2 (1976), 161-72; and Regis Labourdette, "Rcmarques sur la disposition originelle du portail de Souillac," Gesta, XVIII/2 (1979), 29-35.

12 Schapiro, "The Sculptures of Souillac," $117 \mathrm{ff}$.

13 The only other tympanum dedicated to this theme appeared morc than one hundred years later. This was on the north transept portal of the Cathcdral of Notre Dame in Paris (1260), while the western facade maintains the traditional hierarchy with an image of Christ in the Last Judgment in the centre doorway.

14 Labourdctte, "Remarques sur la disposition originelle," 29-35.

15 Labourdette does not provide an explanation as to why the portal was not built. In my forthcoming book on the portal sculptures, 
tentatively titled, The Devil, Voracious Beasts and the Fear of Dying: Rhetorics of Violence and Submission in the Romanesque Portal at Souillac (Chicago University Press), I suggest that the ambitious original plan may have to do with Souillac's efforts to become an independent abbey rather than the dependant monastery that it was, subject to the control of its mocher abbey, Aurillac. Litigation on this issue had been going on for a number of years, when a Papal Bull issued in Rome around 1154 finally thwarted Souillac's efforts at independence. Souillac had been one of the earliest and most important foundations of the Abbey of Aurillac on land donated by its founder, Count Gerald, in the tenth century. It would appear that the monastery at Souillac functioned like a priory, although its head was called a dean, a number of whom went on to become abbots of Aurillac. For a general historical account of the town of Souillac, see Abbé P. Pons, Souillac et ses environs (Cahors, 1923).

16 Schapiro, "The Sculptures of Souillac," 127, n. 14.

17 Michael Camille commented on the ambiguity of these figures, suggesting that for an audience of monks the imagery might have tapped into monastic anxiety and struggles about sexuality. Camille, "Mouths and Meaning," 50-51.

18 The slight damage to the nose and lip area of this figure even adds a sense of repugnance, suggesting that his face is rotting with some leprous disease. The painful expression of this figure is in marked contrast to the bland and incommunicative faces of other figures in the Souillac portal. Only Isaac betrays the fear he is trying to conceal with the tiny rippling furrows above his brow. I will be arguing for a complex interpretation of this bodily and facial expression, one that includes physical pain, shame and fear. Another monument that uses different tactics to express a moral lesson comparable to that of Souillac, the Last Judgement tympanum at Autun, also portrays wonderfully expressive figures in its rising dead. The theme there, however, is not physical pain, but rather joy and excitement of the rising elect versus fear and dread in the rising sinful dead (who seem already to know their fate even before judgement), some of which display terrified masks of horror on their faces. Equally interesting is the way dread or joy is expressed through the comportment of the body as well. The tormented damned in the Last Judgement tympanum at Conques, as will be discussed later, are surprisingly bland in their facial expressions in spite of their excruciating torments.

19 Elaine Scarry, The Body in Pain (Oxford, 1985).

20 Georges Duby, "Observations on Physical Pain in the Middle Ages," in Love and Marriage in the Middle Ages, trans. Jane Dunnett (Cambridge, 1994), 168.

21 Literature on the role of pain in the Late Middlc Ages has become quite extensive. For a general discussion considering discourses and practices in three domains, theology, law and medicine, see Esther Cohen, "Towards a History of European Physical Sensibility: Pain in the Later Middle Ages," Science in Context, VIII, 1 (1995), 47-74. While these discourses and practices differed significantly, they all shared a belief that pain could be useful for certain ends. For an interesting discussion of the relationship between Christian ritual and especially monastic ascetic practices as the early germinating ground for the thirteenth-century development of the practice of judicial torture for determining truth (where pain is connected with the objectification of truth), see Talal Asad, "Notes on Body and Truth in Medieval Christian Ritual," Economy and Society, XII, 3 (1983) 287-327. For the role of pain in Late Medieval art, see Michael Camille, "New Visions of God," Gothic Art, Glorious Visions (New York, 1996), 103-31; H. Van Os, The Art of Devotion in the Late Middle Ages in Europe 1300-1500 (London and Amsterdam, 1994); and M. B. Merback, The Thief, the Cross and the Wheel: Pain and Spectacle of Punishment in Medieval and Renaissance Europe (Chicago, 1999).

22 The seemingly contradictory view that peasants were natural labourers but would be lazy and cheat unless coerced into submission was, according to Paul Freedman, a common view in elite literature throughout the Middle Ages. See Paul Freedman, Images of the Medieval Peasant (Stanford, 1999), 146-49.

23 Cited in Peter Haidu, The Subject of Violence: The Song of Roland and the Birth of the State (Bloomington and Indianapolis, 1993), 2. from Marc Bloch, La Société féodale, (Paris, 1981), I, p. $567 \mathrm{f}$.

24 Duby, "Observations on Physical Pain," 169.

25 Cohen, "Pain in the Later Middle Ages," 62. Even when judicial duels or the ordeal were used to determine guilt, which certainly would result in pain, as when the hand was put into a pot of boiling water, the accused often volunteered himself, and the issue was not pain experienced but, rather, whether or not the wound would heal within a short lapse of time, or in the case of the duel, who would win. The result was thought to be a judgement of God.

26 For this social context of violence and the religious response, sce Lester K. Little, Benedictine Maledictions: Liturgical Cursing in Romanesque France. (Ithaca and London, 1993); and Thomas Head and Richard Landes, eds, The Peace of God: Social Violence and Religious Response in France around the Year 1000 (Ithaca and London, 1992).

27 Scarry, The Body in Pain, 3-59, esp. 13-19 and 57-59. A second means of signifying pain, not portrayed to much extent in Romanesque art but used greatly in the visual representations of the Late Middle Ages, is to picture the bodily damage that accompanies pain. This is what Merbach focuses on in his discussion of a spectacular range of grisly Calvary images, mostly produced in Germany in the lace fifteenth and early sixteenth century, where the bodies of the Two Thieves are gruesomely broken and lacerated. Merback, The Thief, the Cross and the Wheel.

28 Jean-Claude Bonne, L'art roman de face et de profil: Le tympan de Conques (Paris, 1984), $268 \mathrm{f}$.

29 One of the demons carries a pickaxe, a peasant's tool, not a noble warrior's weapon and the weapons are paraded almost humorously rather than held for effective use (the arbalest and shield are backwards). For a discussion of this imagery see Bonne, Le tympan de Conques, p. 289-91. For expressions of medieval sociery's (the clite, of course) contempt for those who labour, the peasants, sce Freedman, Images of the Medieval Peasant. In Part 3, "Unfavorable Images of Peasants," 133-173, he outlines the durable clichés that describc peasant appearance which charactcristically portray them as misshapen (unnaturally large or dwarfish), deformed, dark, 
hairy, with ugly faces and bestial features, all descriptors that could work equally well to describc typical representations of demons as on the tympanum of Conques.

30 The figure of a king bearing gifts, often identified with Charlemagne, Conques' legendary benefactor, is portrayed among the elect led by an abbot towards God.

31 This was already noted by Schapiro in 1939 but has been little addressed since. Schapiro, The Sculptures of Souillac, 121. Casual observers of the pillar too often neglect the focus on the single human figure and wrongly see the pillar as a confused tumult of devouring beasts, when, in fact, it is a very orderly design.

32 For other studies that have remarked on the significance of this development in monastic spirituality, see Kathryn Horste, Cloister Design and Monastic Reform in Toulouse: The Romanesque Sculpture of La Daurade (Oxford, 1992), 157-90; also Sharon Farmer, The Communities of Saint Martin: Legend and Ritual in Medieval Tours (Ithaca and London, 1991), 117-50.

33 For more on this, see Cowdrey, The Cluniacs and the Gregorian Reform, 128-35.

34 How this new subjectivity, so different from earlier Greco-Roman traditions, was cstablished in the Early Christian Era and how it contributed to the institutionalization of the Church has been finely elucidated by Judith Perkins in her recent book, The Suffering Self. Pain and Narrative Representation in the Early Christian Era. (London and New York, 1995).

35 For an evocative description and discussion of this relief along with more detailed photographs, see Meyer Schapiro, "The Romanesque Sculpture of Moissac II," Romanesque Art (1931; repr. New York, 1977), 230-47. The Moissac rendition is a graphic representation of the popular parable of Christ recounted in Luke 16. 1931. While the story as a whole alludes to the Last Judgement, the biblical lesson seems to suggest that it is precisely Lazarus' life of painful suffering, through no fault of his, that merited for him an afterlife of comfort. Luke 16. 25: "And Abraham said to him [Dives suffering in hell]: Son, remember that thou didst receive good things in thy lifetime, and likewise Lazarus evil things, but now he is comforted; and thou art tormented."

36 Ironically, the biblical text of Lazarus and Dives appears to spurn Dives' plea to Abraham to go and warn his brothers of his fate in hell in order for them to repent while they can. Yet, of course, this is precisely the intent of the telling of the parablc and a major lesson of the portal as well. The story at Moissac is clearly intended to be a warning to the avaricious, as highlighted in the emphasis on the money bags, a commonly used symbol for Avaritia (held by a demon in the death bed scene and weighing down the neck of the figure tormented in hell below, coupled in torment with the nude figure of licentious woman, Luxuria). At the same time the portrayal would serve as a consolation to the poor and destitute who might very well have sat begging at the entrance to the church. Judging from the hat worn by the rich man feasting at the table, Dives is personified here as a rich merchant or burgher. However, amongst the potential public, there are a number of social types who could have been configured in these identities. Historically problematic enemies at Moissac at this time were a group of feudal warriors, former lay abbots whom the monks had accused of plundering monastic property. The abbots of Moissac had only recently gained a certain independence in relation to these warriors. Also, as I have said, I azarus, could stand as a figure for the life of a monk. Pilgrims who travelled to Moissac might identify both with the Rich Man and be encouraged to donate or give to the poor or, as pilgrims who have temporarily given up the world and often sought lodging, they might identify with Lazarus. The tympanum at Moissac, on the other hand, has a very triumphant appearance. Probably made some fifteen to twenty years before the porch sculptures, it portrays a very regal crowned and enthroned Christ of the Second Coming and can be interpreted metaphorically as referring to the abbey church itself asserting its position both spiritually and temporally. For discussion of Moissac, see Elisabeth Magnou, "Abbés séculiers ou avoués à Moissac au XIe siècle," Moissac et l'Occident. Actes du Colloque Internationale de Moissac (1963) (Toulouse, 1964), 447-56; Charles F. Altman, "The Medieval Marquec: Church Portal Sculpture as Publicity," Journal of Popular Culture, XIV (1980/81), 37-46; Peter K. Klein, "Programmes eschatologiques, fonction et réception historiques des portails du XIIe siècle: Moissac, Beaulieu, Saint-Denis," Cahiers de civilisation médiévale, XXXIII/4 (1990), 317-49.

37 A discussion of monastic prayer and liturgy especially related to the theme of devouring beasts and consequences for the interpretation of the Souillac pillars is presented at length in my forthcoming book, The Devil, Voracious Beasts and the Fear of Dying.

38 For Cluny, see Noreen Hunt, Cluny under Saint Hugh, 1049-1109 (Notre Dame, Indiana, 1967), 117-23.

39 Thus, in the Carolingian era, as Esther Cohen pointed out, it had been true that "any layman forced to undergo a ritual of public penitence," which often entailed just these sorts of punishments, "was debarred for life from bearing arms and filling public office." Cohen, "Pain in the Later Middle Ages," citing Mayke De Jong, "Power and Humility in Carolingian Sociery: The Public Penance of Louis the Pious," Early Medieval Europe, I (1992), 33-34.

40 Talal Asad, "On Ritual and Discipline in Medieval Christian Monasticism," Economy and Society, XVI/2 (1987), 157-203, esp. 192, which describes these practices in depth as a precursor to social transformation. Foucault, of course, inspired Asad in this argument. The telling of warning tales would also reinforce proper attitudes. Speaking about the monastery of Marmoutier in the twelfth century, Sharon Farmer comments on the way that monks in this era were made to feel more and more individually responsible for the care of the souls of their brothers. In one tale physical pain delivered by the dead is punishment for improper actions. This is the story of a monk, Ulrich, who had been living rather independently away from the main community at a priory. Thinking that no one would notice, he absconded with some of the money designated for prayers for the souls of the monks. He was visited in his dreams by two dead brothers who rebuked him, but he took little heed. On the third attempt "they gave him so many floggings that he remained in bed for half a year tortured by the most sever pains." Farmer, The Communities of Saint Martin, 144. 41 Asad, "Ritual and Discipline in Monasticism." See also Haidu, The 
Subject of Violence, 72, for a discussion of the Culture of Shame. As he says, "In a society founded upon 'honor' [with its contrary, shame], the value of the individual is not detached from the judgments of his peers. Whether he retains his value or not depends directly, unmediatedly, upon the good opinion they have of him." Also, for noble feudal vassals, "honor is the social and objective valuation of the individual by the society of his peers, the valuation that constitutes him both as a social object of value and as the narrative subject of actions attributed to the noble. Honor is the ultimate value in that set of values that constitutes the noble ideology of the Chanson de Roland, taking ideology both as it constitutes the Subject by interpellation and as it provides for the lived relation of men to their real conditions of existence." This would be different from the succeeding culture of guilt that assumes a higher authority through which the subject can be reinscribed in sociery through confession. And at the same time, the Subject can have a sense of autonomous value, because not defined by peers, but by some higher authority (state/God). To some extent, as I argue for Souillac, Peter Haidu maintains that the Song of Roland, though on the surface appearing to be a thorough embodiment of the warrior ideology of a culture of honour and shame, has embedded within it the seeds of the new sensibility to come, "the lineaments of the nascent State ... requiring the creation of new Subjects, and a new form of Subjectivity. Ours." Haidu, The Subject of Violence, 210.

42 Discussed in the context of the ritual humiliation of saints by Patrick Geary, "Humiliation of Saints," Living with the Dead in the Middle Ages (Ithaca and London, 1994), 95-115, esp. 101.

43 This representational topos of knights facing off equally in batcle finds its parallel in the Song of Roland where care is taken to portray the Saracens, although the enemy, as valiant and noble warriors. A similar ideology about the equality of the warrior class is found in the extended narrative imagery of the Bayeux Tapestry where English and Normans are both valiant when fighting each other. At Conques one can encounter several late eleventh-century capitals of paired fighting warriors in the tribunes where the laity were accustomed to congregate during the all-night vigils of the Feast of Sainte Foy. This is not to say that knights never put themselves in a position of supplication. They did do this in situations that demanded respect for authority: in the presence of kings or royally invested officials and in religious settings of supplication and before ecclesiastical officials. For the social importance of rituals of supplication, see Geoffrey Koziol, Begging Pardon and Favor. Ritual and Political Order in Early Medieval France (Ithaca and London, 1992). However, in medieval western culture, it is quite rare to find a visual representation of a lay noble in total supplication before another. In images of homage between a vassal and his Lord, the vassal bends only one knee in recognition of the superiority of his lord. The distinction between the gesture of the vassal and the more prostrate attitude of the religious penitent can be seen at Souillac in the differing portrayals of Theophilus (fig. 5).

44 The Song of Roland, trans. Glyn Burgess (London, 1990), 89.

45 This was the argument put forth by Barbara Rosenwein to suggest a psychological basis for the tremendous growth of time spent in liturgical functions at Cluny in the eleventh century. "Cluniac Liturgy as Ritual Aggression," Viator, II (1971), 121-57. See also the discussions of spiritual struggle in Conrad Rudolph, Violence and Daily Life: Reading, Art, and Polemics in the Cîteaux Moralia in Job, (Princeton, 1997).

46 Song of Roland [11. 2385-2396], 105.

47 "The Orientalizing Period" is the name typically used by art historians to designate an era in Ancient Greek art during the seventh century B.C. when stylized animal imagery composed of both real and mythical beasts adapted from Near Eastern traditions came to predominate in pictorial imagery of Greece. Similar imagery can be found in the art of Etruscans and in Early Medieval Art in both secular and religious contexts.

48 Unfortunately, it is hard to appreciate the importance that these Near Eastern luxury items had in the context of the warrior feudal culture since so much has perished. However, the Song of Roland, where violence and booty go hand in hand, is full of references to fabled and coveted Islamic treasure. Ganelon, who eventually became a traitor to the Franks, at his meeting with the Muslim King Marsile is described as decked in "a cloak of sable, lined with silk from Alexandria" [11.462-463], 57. Later, when Charlemagne finally discovers the bodies of his loyal vassals, he has the hearts of Roland, Archbishop Turpin and Oliver taken out, wrapped in silk cloth and placed in marble caskets. Their bodies were then enveloped in stag skins, placed on carts completely covered with silk from the Near East (Galatia) [2962-2973].

49 Compare to ivories and silks discussed in the section on "Decorative Arts" in Chapter 4, "The Muslim West: 750-1260," in Richard Ettinghausen and Oleg Grabar, The Art and Architecture of Islam 650-1250 (London, 1991), 145-66.

50 The Song of Roland [30-33; 125-34;180-87].

51 The memory of these horns, forever attached to the notion of heroic valour, has come down to us today through the Song of Roland and the vital place the oliphant of Roland played in this story. Roland had refused to blow his horn to call back Charlemagne and his troops, because he was too full of pride (his flaw) thinking this would be a cowardly and shameful act. This ultimately caused the downfall of the rear guard. Ironically, it is when he is finally forced to blow the horn to signal the alert (against his concept of valour), that Roland is finally said to suffer pain:

Count Roland with pain and distress

Sounds his oliphant in great agony.

The clear blood gushes forth from his mouth

And in his skull the temple bursts.

Charles hears it, as he makes his way through the pass.

The Song of Roland, [II. 1761-1766], 146.

Later Charlemagne takes the oliphant back to France and, full of gold, places in on "the altar of the noble Saint Seurin" in a church in Bordeaux.

$52 \mathrm{H}$. Swarzenski, "Two Oliphants in the Museum," Bulletin, Museum of Fine Arts, Boston, LX (1962), 27-45.

53 The casket was described in a 1440 inventory of the abbey as 
containing relics of the eleven thousand virgins who were companions of St. Ursula. For this and a general discussion of this casket, sec: the exhibition catalogue from the Metropolitan Museum of Art, The Art of Medieval Spain a.d. 500-1200 (New York, 1993), 273-76.

54 There is a floriated Kufic inscription on this caskct, partially destroyed, but with enough information to suggest that the ivory was made for a sovereign in the city of Cuenca in 1026. Art of Medieval Spain, 274. For interesting discussions of other Islamic ivories of th:s sort that entered church treasuries in Spain, see O. K. Werckmeister, "Art of the Frontier: Mozarabic Monasticism," Art of Medieval Spain, 121-32; Juile A. Harris, "Muslim ivories in Christian hands: the Leire Casket in context," Art History, XVIII (1995), 213-21; Francisco Prado-Vilar, "Circular Visions of Fertility and Punishment: Caliphal Ivory Caskets from Al-Andalus," Mirqarnas, XIV (1997), 19-41. My thanks to John Williams for giving me the reference to this last article.

55 When associated with royalty, this battle imagery could take on symbolic importance in reference to cosmic battles that maintain natural order (good/evil, night/day, life/death, etc.). That secular works like these, many from non-Christian countries, including precious silks with similar imagery, entered into ecclesiastical treasuries to wrap or house relics of saints should not be surprising. Af art from the precious materials and fine workmanship so prized, the heroic themes of triumph over danger, ferocious enemies and death are perfect metaphors (indeed, well established literary topoi as well) to describe the triumph of saints. This would be an example of the church adopting this heroic ethos for the message of triumph it could impart.

56 Francisco Prado-Vilar in his interesting article on the Caliphate ivory caskets discusses the manipulation of this tradition of power imagery whereby the portrayal of attacking animals of prey are veiled political threats against enemies. Usually the lions attack clearly weaker victims like stags, their natural prey, but on one ivcry pyxis he analyses, as can be seen in the Silos example as well, the victim is a bull, normally considered a strong animal. Since the object, was a gift from a caliph to a potential rival, Prado-Vilar arg,ues, in this manipulation of the tradition, that this would have been understood as a warning to this person of otherwise high rarık, "affirming the hegemony against peers of close status." PradoVilar, "Circular Visions," 24-27. The pairing of lions and griffins has: a long tradition. A very early heroic image of lions and griffins attacking a stag was seen as fitting decoration on a Sythian sword scabbard (4th c. B. C., Kiev Historical Museum). Clearly the intent was to equate the ferocity and strength of the sword handler with that of these ferocious beasts.

57 Another popular motif from this heroic tradition that the Souillac image appears to be directly negating is that of the heroic Master of Animals. Often portrayed as a stylized human standing centrally between two animals that he grasps or fends off with his two arms, implying the human domination over animal forces, this image can be seen in a variety of contexts since its appcarance in Ancient Mesopotamia. There is a Roman bronze that portrays just such a fig are fending off griffins illustrated in Roger Hinks, "The Master of Animals," Journal of the Warburg Institute, V. I (1937-38), 26365.

58 Pamela Sheingorn, trans., The Book of Sainte Foy (Philadelphia, 1995), 135. Miracle 2:9.

59 The Song of Roland, [1. 1888] and [1. 1874], 89.

60 John C. Hawthorne and Cyril Stanley Smith, eds, On Diverse Arts, The Treatise of Theophilus (Chicago, 1963), 157.

61 See, for example, the so-called Throne of Dagobert, a Carolingian work once associated with the Royal Abbey of St. Denis and now in the Cabinet des Médailles of the Bibliotheque Nationale in Paris. For an illustration, see Magnus Backes and Regine Dölling, Art of the Dark Ages (New York, 1969), 77. There are countless medieval manuscript images of figures in authority on lion-headed thrones. The concept goes back to the portrayal of gods in ancient Mesopotamia where it carried an association with ideas of apotheosis and in the Judeo-Christian tradition to the precedent of the throne of King Solomon flanked by six pairs of lions on its steps.

62 In a recent article on the trumeau and lintel of Moissac, Piotr Skubiszewski has called attention to the generative symbolism also embedded in the trumeau imagery. Rightly pointing to the flowered roundels that cover both the lintel and trumeau, he argues that the two sculpted pieces should be seen together as a Tau cross. This reference to the Flowered Cross and Tree of Life concept, together with the male/female lions on the trumcau, call attention to creation themes and regeneration. Yet, I would argue, this does not negate the guardian functions the lions serve as they actively survey and guard the door's entryways. See Piotr Skubiszewski, "Le trumeau et le linteau de Moissac: un cas du symbolism médiéval," Cahiers Archeologiques, 40 (1992), 51-90.

63 The "orientalizing" style of animal imagery here at Souillac is a key factor to this effect. It specifically interpellates the heroic subject as no other style of devouring beast image would. There are, in fact, countless images of devouring beasts, monsters and snakes in Romanesque art, but not all partake of this visual style. They would not create the same effect I am describing here. The theoretical concepts that underpin this argument about the psychological impact of these sculpted images make use of some theories from Jacques Lacan. A useful discussion of the value of these psychoanalytical models for cultural criticism can be found in Mark Bracher, Lacan, Discourse, and Social Change: A Psychoanalytic Cultural Criticism (Ithaca and London, 1993).

64 Although I am inclined to agree with Labourdette's theory that the portal sculptures faced into the porch during the Middle Ages (see above, note 11), the lesson serves equally well for both monks and laity with the portal sculptures set up as they are now on the interior west wall. In this case, those who had been in the sacred space of the church would see them as they were about to depart into the profane world. The sculpture would be a warning to monks not to get caught up in the worldly pleasures of the warrior ethos. As a departing reminder for the laity, they would put a check on any easy falling back into the confidence of the heroic subjectivity once outside the church.

65 These points are developed more fully in my forthcoming book, The Devil, Voracious Beasts and the Fear of Dying. Let me insist, 
however, that within the iconography of medieval art this image cannot be said to be a damned person tormented in hell. Wild animals like this are never tormentors the way demons are, although they sometimes have the function of carrying the dead towards hell or judgement as can be seen on the tympanum of Beaulieu. The Souillac image is more metaphorical than that, calling up the notion of death itself and worries about the state of the soul.

66 A common simple format for the imagery of Daniel in the Lion's Den, since the art of fourth-century catacombs (Catacomb of the Jordani) and continuing in Early Medieval art (San Pedro de la Nave, Merovingian tombs), was to portray Daniel in the centre with two lions placed antithetically on either side who lick his feet or otherwise abstain from harming him. The lions on the capital from Moissac illustrated here have stylistic affinities to the lions at Souillac. The imagery derives from the heroic formula of the "Master of Animals" motif (The Lyre of Ur, the Sutton Hoo Purse Lid, Burgundian Belt Buckles). For further discussion, see Hinks above, nore 57. However, Daniel uses prayer rather than muscle to fend off animals. In a more complex narrative portrayal, Daniel in the Lions' Den is the theme of the left porch relief in the portal of the Abbey Church at Beaulieu where it serves as a contrast to the souls attacked by beasts in the Last Judgement tympanum above. Clearly bearing a relationship to the figure of the man attacked by beasts at the top of the Souillac pillar, but in a less formalized portrayal, the striding beasts grasping onto human figures (including a paired lion and griffin as at Souillac) on the top lintel at Beaulieu, do not portray sinners tormented in hell as is sometimes assumed. Rather, these beasts are transporters, aggressively carrying these human figures to their judgment.

67 Art historians tend to consider only direct iconographic parallels to be valid. The Souillac pillar has been problematic for iconographic interpretation because, although the imagery seems in some ways "hellish," such attack by wild beasts without the presence of demons does not conform to known iconographies of Hell. As I argue, more subtle forms of interpretation have to be developed, including the recognition of meaning embedded in stylistic form and composition and the construction of meaning through reversal of expectation.

68 Frederick S. Paxton, Christianizing Death: The Creation of a Ritual Process in Early Medieval Europe (Ithaca and London, 1990), 11622, 130-31, 167-69. In the Catacomb of Priscilla (early third century) one can find a number of the figures later to be included in the Commendatio Animae ritual: Daniel in the Lions' Den, Three Hebrews in the Fiery Furnace, Jonah saved from the Whale, Abraham and Isaac, Lazarus raised from the Dead.

69 After confessing his sins he prayed to God:

True Father, who has never lied,

You who brought back Lazarus from the dead

And rescued Daniel from the lions,

Protect my soul from every peril

And from the sins which I have committed in my life.

Song of Roland, 105 [11. 2385-2396].
70 The abbot represents the authority of the monastic institution while St Peter represents the papacy in Rome and Peter's keys, the church's power, handed down to priests, to "loose and to bind."

71 Originally a sixth-century Greek account, the Theophilus story only became available in the west in the ninth century after it was translated by Paul the Deacon. This was first edited in Acta Sanctorum, I, 483ff.; also reprinted in R. Petsch, ed., Theophilus: Mittelniederdeutsches Drama in drei Fassungen (Heidelberg, 1908). For further discussion of the range of literary texts which shows how popular this legend (the source for Faust) eventually became, see Alfred Freyer, "Theophilus, the Penitent, as Represented in Art," The Archeological Journal, XCII (1935), 287-333, esp. 290 and n. 1; also Karl Plenzat, Die Theophiluslegende in den Dichtungen des Mittelalters (Berlin, 1926).

72 According to the original story, Theophilus had worked for a church in Adana (Asia Minor) as lay administrator. Because he was so well liked, he was nominated to be Bishop upon the death of the former Bishop. Too humble, Theophilus refused this honour. However, to his dismay the new Bishop promptly relieved him of his old duties. At this Theophilus grew bitter and sought the help of a Jew (not shown at all in the Souillac rendition but a common feature of later thirteenth-century iconography), who in turn arranged a meeting and introduced Theophilus to the Devil. The Devil agreed to help him get back his lucrative and prestigious position and become even more powerful and rich, if he agreed to take the Devil as his Lord and deny God. This he did, but eventually began to suffer remorse and fear of the consequences of his acts at the time of Judgement. Therefore, he left to go to a chapel dedicated to the Virgin Mary and prayed and fasted ardently for forty days, a typical penitential practice, whereupon the Virgin appeared and eventually returned his contract. Although not shown at Souillac, the literary texts say that he went back to the cathedral on a Sunday while the Bishop was about to say mass, interrupted the ceremony to tell his dramatic tale and show his contract as evidence. The Bishop took the opportunity to give a sermon on the virtue of penitence and devotion to the Virgin and then dramatically burned the contract. Theophilus whose face shone like the sun, soon died in an odour of returned sanctity. For a comprehensive discussion with observations on other visual portrayals of the Theophilus Legend, see Freyer, "Theophilus, the Penitent, as Represented in Art." What would have been significant for a Medieval audience of the twelfth century is that the term uscd to describe Theophilus' function was vicedominus or vidame in French. In the Medieval era a vidame was often a knight who was given a fief by an ecclesiastical establishment in order to protect the church's property. It was not uncommon for there to be friction between the vidame and his ecclesiastical overlords.

73 O.K. Werckmeister has called attention to the significance of the liturgy for the dead in his interpretation of a number of visual works of the Romanesque era. See "Die Auferstehung der Toten am Westportal von St. Lazare in Autun," Frühmittelalterliche Studien, XVI (1982), 208-36; idem, "The First Romanesque Beatus Manuscripts and the Liturgy of Death," Actas del Simposio para el Estudio de los Codices del 'Comentario al Apocalipsis' de Beato de Liebana, 
vol. 2 (1980), 167-92. A lengthier discussion of psalms and liturgical prayers and antiphons in relation to the theme of attack by beasts will be presented in The Devil, Voracious Beasts and the Fear of Dying , forthcoming.
74 G. Camy and M. Labrousse, "L'Église Abbatiale Sainte-Marie de Souillac, sa tour-porch et sa necropole," Bulletin Monumental, CIX/4 (1951), 389-403. Medieval sarcophagi in the crypt crossed the threshold between the porch and the church. 